\title{
HIGH-DENSITY SUSPENSIONS FORMED UNDER WAVES
}

\author{
MICHAEL P. LAMB ${ }^{1}$ AND JEFFREY D. PARSONS ${ }^{2}$ \\ ${ }^{1}$ University of California-Berkeley, Earth and Planetary Science, Berkeley, California 94720, U.S.A. \\ ${ }^{2}$ University of Washington, School of Oceanography, Seattle, Washington 98195, U.S.A. \\ e-mail: mpl@berkeley.edu
}

\begin{abstract}
We performed a series of laboratory experiments to investigate the interactions of a turbulent wave boundary layer with a predominantly silt-size sediment bed. Quasi-steady, turbulent, highdensity suspensions (HDS) formed over a wide range of wave conditions and had near-bed ( $\sim 1 \mathrm{~mm}$ above bed) concentrations ranging from 17 to $81 \mathrm{~g} / \mathrm{l}$ scaling roughly with the wave orbital velocity. HDS were defined by the presence of a lutocline, an abrupt change in vertical concentration gradient. Despite the initial bed being $70 \%$ silt and $20 \%$ sand, HDS had significant near-bed sand fractions ranging from 27 to $78 \%$. Winnowing of the bed caused more concentrated HDS to be coarser grained, which in turn caused the suspensions to be thinner because of the greater settling velocity of the sediment. Our experiments are consistent with a dynamic feedback model where suspended sediment is limited through sediment-induced stratification expressed with a bulk Richardson number. However, our computed values of the bulk Richardson number converge to a value that is an order of magnitude less than the critical value of 0.25 that is typically assumed. The experimental wave orbital velocities $(15-60 \mathrm{~cm} / \mathrm{s})$ and periods $(3-8 \mathrm{~s})$, as well as the characteristics of the HDS and the bed in our experiments, were comparable to observations made on the Eel shelf, California, during storm conditions when fluid mud has been observed.
\end{abstract}

\section{INTRODUCTION}

The processes that transport sediment across continental shelves and ultimately control shelf sedimentology and morphology have been debated for over twenty-five years. For example, evidence from the geologic record suggested to early workers that storm-induced turbidity currents were an important, if not dominant, process in cross-shelf transport (Hamblin and Walker 1979; Walker 1985a; Walker 1985b). However, oceanic observations indicated that storms produced shore-parallel geostrophic flows, not turbidity currents (Swift et al. 1986). Recent studies on the Eel shelf, California, have pointed to a third possibility. Large storm waves produced near-bed, high-density suspensions (HDS), also called fuid muds, $5-15 \mathrm{~cm}$ thick with near-bed sediment concentrations greater than $10 \mathrm{~g} / \mathrm{l}$ (Ogston et al. 2000; Puig et al. 2003; Traykovski et al. 2000). HDS, when formed on a sloping bed, might lead to significant wave-supported, gravity-driven, cross-shelf sediment transport (Traykovski et al. 2000; Wright et al. 2001). Despite recent field studies, little is known about HDS because detailed measurements inside concentrated suspensions are difficult. For example, one of the better-instrumented studies was that of Traykovski et al. (2000). They were able to measure vertical profiles of suspended sediment concentration, but they were unable to measure grain size or sediment concentrations in excess of $\sim 10 \mathrm{~g} / \mathrm{l}$. Wright et al. (2001) have suggested a simple model to predict the concentration of HDS through the use of a critical bulk Richardson number. Unfortunately, such a model cannot yet be tested quantitatively because of the limited field measurements.

In order to address this knowledge gap we conducted a series of exploratory experiments using a laboratory wave facility with a primarily siltsize sediment bed. While experimentalists have analyzed wave boundary layers over immobile beds (e.g., Jensen et al. 1989; Justesen 1991) and over mobile sand beds (e.g., Arnott and Southard 1990), to our knowledge we present the first experimental study to produce turbulent wave boundary layers over a fine-grained sediment bed where large concentrations $(>10$ $\mathrm{g} / \mathrm{l})$ of sediment were suspended. In this paper we focus on (1) what wave conditions produce HDS, (2) what parameters set the height, concentration, and grain size of HDS, and (3) what bed morphology and depositional stratigraphy result from HDS. In addition, we compare our results to field observations and models, and discuss the implications of our study to shelf sediment transport.

\section{EXPERIMENTAL FACILITY}

The experimental wave facility is a U-tube consisting of a sealed test section and two end tanks (Fig. 1). One end tank serves as a standpipe with a free surface, and the other contains a motor that drives a piston. When the U-tube is filled with water, forcing from the piston produces nearly sinusoidal horizontal oscillations in the test section that span wave periods of 3 to 8 seconds and wave orbital velocities of 15 to $60 \mathrm{~cm} / \mathrm{s}$. The U-tube does not produce true orbital motions, which are typical of water motion under surface gravity waves near a free surface; rather it produces horizontally oscillating motions, which are typical of surface-gravity-wave motions near a fixed boundary (e.g., the seabed). During larger periods $(>5 \mathrm{~s})$ and wave orbital velocities $(>40 \mathrm{~cm} / \mathrm{s})$ the oscillations develop slight asymmetries because these conditions deviate from the natural period of the U-tube.

Plastic honeycomb in between the test section and the end tanks (Fig. 1) minimize turbulence from the end tanks, such that turbulent fluctuations are held to less than $10 \%$ of the orbital motions (Lamb et al. 2004). Therefore, the majority of the turbulence near the walls in the test section is produced at the boundaries. Although the test section is only $20 \mathrm{~cm}$ wide, the side boundary layers are not a significant fraction of the width $(<10 \%)$ and therefore do not significantly influence the water column. The facility is equipped with a roughened false floor (120 grit sand paper), making the bottom boundary layer thicker than the side boundary layers. In sedimentfree conditions the bottom boundary layer is consistent in vertical form to previous field, laboratory, and theoretical studies (Lamb et al. 2004).

The piston seal is not completely waterproof, so that throughout an experiment, water leaks from the U-tube into the upper portion of the piston chamber. A small overflow pump returns this water to the U-tube via the downstream end tank, so that the water level is constant during an experiment. This water displacement produces a slight current $(<3 \mathrm{~cm} / \mathrm{s})$ in the test section, which is assumed negligible because it is much slower than the wave orbital velocity.

\section{EXPERIMENTAL PROCEDURE}

Two different sets of experiments were performed in the U-tube. The first used freshwater over a predominantly silt-sized sediment bed (Fig. 2), and the second used a dense bottom saline layer over the immobile false floor. These two sets of experiments will be referred to as the sediment and the saline experiments, respectively.

For each experiment velocity measurements were taken with a microacoustic Doppler velocimeter (ADV). The ADV was used to measure the orbital velocity $U_{o r b}$ and the period $T_{w}$ of the waves for each experiment (Table 1). $U_{o r b}$ is defined as $\sqrt{2} U_{r m s}$, where $U_{r m s}$ is the root-mean-square of the streamwise velocity. $T_{w}$ was calculated from every second zerocrossing in the streamwise velocity time series. Both $U_{o r b}$ and $T_{w}$ were calculated on the basis of an average of the free-stream data (i.e., data 


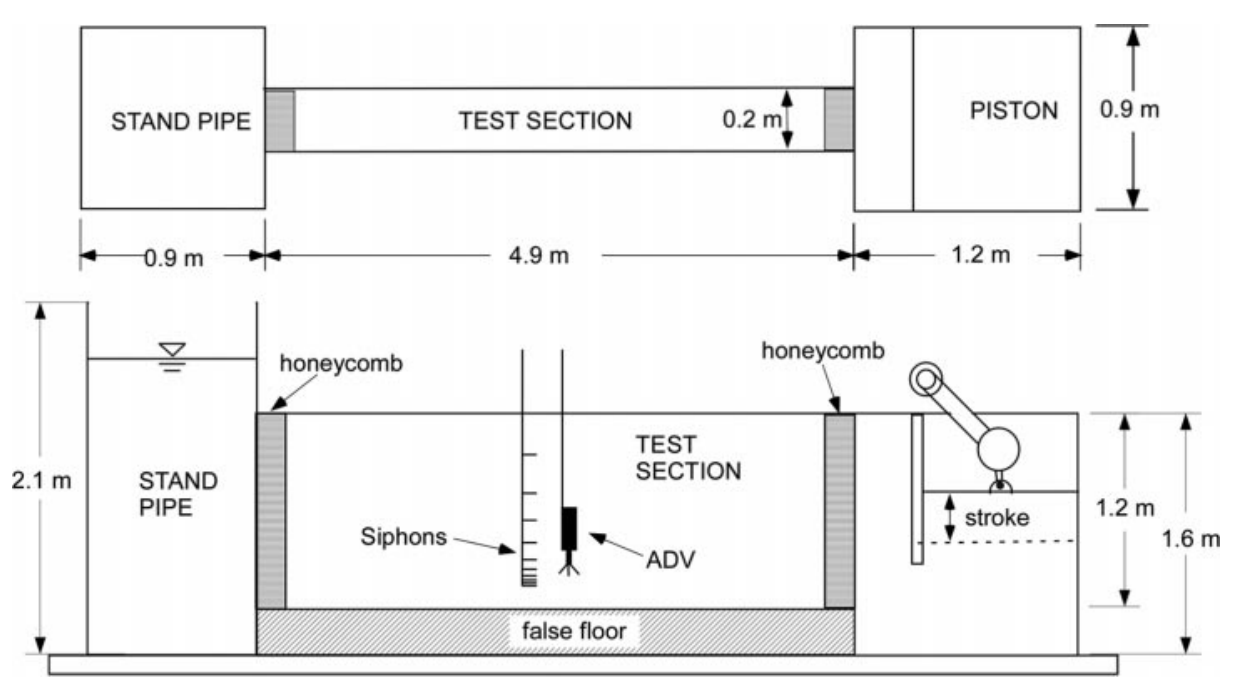

FIG. 1.-Schematic of experimental U-tube in plan view (top) and side view (bottom). taken well outside of the boundary layer, i.e., $z>10 \mathrm{~cm}$, where $z$ denotes the vertical height above the bed). The wave excursion amplitude for each experiment is defined as $A \equiv U_{o r b} T_{w} / 2 \pi$. A modeled bed shear velocity $u_{* g m}$ was calculated following Grant and Madsen (1979), where $U_{o r b}, T_{w}$, and a hydraulic roughness scale $k_{s}$ were input parameters. For the sediment runs, $k_{s}$ was estimated as $4 \eta$ when ripples were present, where $\eta$ is ripple height (e.g., Wikramanayake and Madsen 1990), and $0.1 \mathrm{~cm}$ in plane-bed conditions.

In addition to velocity measurements, water samples were taken during the sediment experiments. A rake of 11 vertically stacked siphons, each with an inside diameter of $2.1 \mathrm{~mm}$, was mounted near the ADV in the test section (Fig. 1). The vertical position of the rake was measured using a scale on the siphon mount, which gave a vertical error of $\sim 1 \mathrm{~mm}$ based on repeated measurements. During an experiment the rake was placed such that the lowermost siphon rested on or was just above the bed. Two sets of siphon samples were taken for each experiment separated by $\sim 60$ minutes, the average of which is given in the Results section. Each $250 \mathrm{~mL}$ siphon sample was taken over a duration of $\sim 20 T_{w}$. To avoid sampling

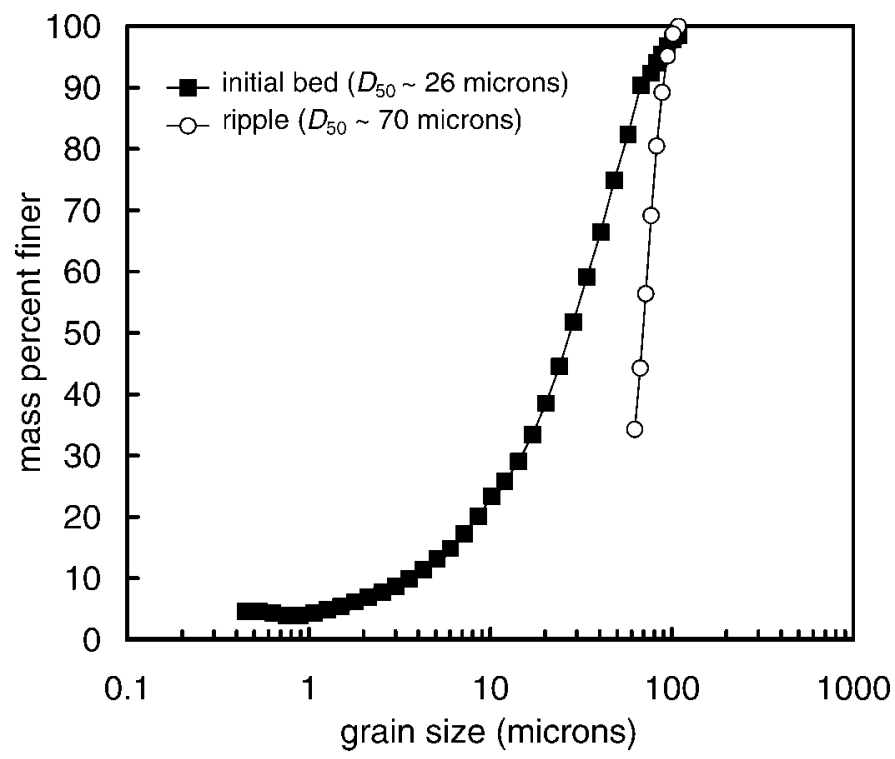

FIG. 2.-Grain-size distribution of the initial sediment bed mixture and of sediment sampled from a ripple. The fine fraction for the ripple could not be analyzed because of the small volume of sediment in this size class. errors, the flow rate in the siphons was of the same order as the wave orbital velocity in the test section $\left(\sim 1 / 2 U_{\text {orb }}\right)$. The samples were weighed and dried to measure the sediment concentration. The dried sediment samples were dispersed and passed through a $63 \mu \mathrm{m}$ sieve. Grain-size distributions were calculated on the sand fraction $(D>63 \mu \mathrm{m})$ using a settling column, and on the silt $(3.9 \mu \mathrm{m}<D<63 \mu \mathrm{m})$ and clay fractions $(D<$ $3.9 \mu \mathrm{m})$ using a Micrometrics SediGraph 5100.

The siphon samples were used to make vertical profiles of volumetric sediment concentration $(c)$ and mean grain size $\left(D_{50}\right)$ for each experiment. The concentration of the lowest siphon sample was defined as the near-bed sediment concentration $\left(C_{b e d}\right)$. For the experiments with HDS, the top of the suspension $(H)$ was defined by a lutocline (i.e., an abrupt change in vertical concentration gradient). $H$ was calculated for each experiment as the height above the bed where the local concentration equaled $10 \%$ of $C_{b e d}$ using a linear interpolation between data points. In order to correct for suspended sediment that might have been due to mixing in the end tanks, the background sediment concentration (defined as the vertically averaged sediment concentration above $10 \mathrm{~cm}$ above the bed) was subtracted from both the local concentration and $C_{b e d}$ before calculating $H$. This measure of $H$ was used because it conveniently yielded lutocline heights consistent with visually observed heights of the HDS and the heights of an abrupt change in concentration gradient measured with the siphons. Depthaveraged grain size $\left(\overline{D_{50}}\right)$ and concentration $\left(C_{\text {ave }}\right)$ inside the HDS were calculated as $\int_{0}^{H} D_{50} c d z / \int_{0}^{H} c d z$ and $1 / H \int_{0}^{H} c d z$, respectively, using a linear finite difference approximation.

\section{RESULTS}

\section{Reynolds Number}

Jensen et al. (1989) suggested that the appropriate form of the Reynolds Number $\mathbf{R}$ for a wave boundary layer is $\mathbf{R}=A U_{o r b} / \nu$, where $\nu$ is the kinematic viscosity of the fluid, assumed to be $0.01 \mathrm{~cm}^{2} / \mathrm{s}$. Wave boundary layers are considered to be turbulent for $\mathbf{R}>10^{5}$. However, Jensen et al. (1989) stress that there are significant parts of the wave half-cycle that are not fully turbulent over a smooth bed even at $\mathbf{R}=10^{6}$. This value is likely an overestimate for the rough beds in these experiments. The computed value of $\mathbf{R}$ for the salt experiment was $2.6 \times 10^{4}$. The computed Reynolds numbers for the sediment experiments range from $0.5 \times 10^{5}$ to $3 \times 10^{5}$ (Table 1). Therefore all of the sediment experiments likely had turbulent wave boundary layers, which is consistent with our visual observations of eddies and measurements of turbulent kinetic energy (Lamb et al. 2004). 
TABLE 1.-Measured and computed values from the 15 sediment experiments.

\begin{tabular}{|c|c|c|c|c|c|c|c|c|c|c|c|c|c|c|c|}
\hline & \multicolumn{15}{|c|}{ Experiment } \\
\hline & S1 & S2 & S3 & S4 & S5 & S6 & S7 & S8 & S9 & S10 & S11 & S12 & S13 & S14 & S15 \\
\hline$U_{\text {orb }}\left(\mathrm{cm} \mathrm{s}^{-1}\right)$ & 21.7 & 23.8 & 28.3 & 30.3 & 31.9 & 37.2 & 41.1 & 30.6 & 33.5 & 44.6 & 55.0 & 52.3 & 40.6 & 38.0 & 38.2 \\
\hline$T_{w}(\mathrm{~s})$ & 6.0 & 7.7 & 5.9 & 4.3 & 7.5 & 5.9 & 7.5 & 6.1 & 4.9 & 4.9 & 5.6 & 4.2 & 6.0 & 5.0 & 4.3 \\
\hline $\mathbf{R} \times 10^{-5}$ & 0.45 & 0.69 & 0.75 & 0.63 & 1.22 & 1.30 & 2.03 & 0.91 & 0.88 & 1.55 & 2.72 & 1.84 & 1.56 & 1.14 & 0.99 \\
\hline$H(\mathrm{~cm})$ & no HDS & no HDS & no HDS & 7.8 & 7.3 & 6.8 & 7.2 & 7.1 & 5.1 & 3.1 & 3.8 & 3.9 & 3.3 & 4.7 & 4.7 \\
\hline$H_{10}(\mathrm{~cm})$ & $\mathrm{n} / \mathrm{a}$ & $\mathrm{n} / \mathrm{a}$ & $\mathrm{n} / \mathrm{a}$ & 3.37 & 1.99 & 2.76 & 3.76 & 2.80 & 3.08 & 3.08 & 9.65 & 7.02 & 2.82 & 4.70 & 4.73 \\
\hline$C_{a v e}\left(\mathrm{~g} \mathrm{l}^{-1}\right)$ & $\mathrm{n} / \mathrm{a}$ & $\mathrm{n} / \mathrm{a}$ & $\mathrm{n} / \mathrm{a}$ & 6.0 & 6.4 & 8.9 & 9.2 & 7.8 & 14.0 & 16.0 & 20.1 & 20.8 & 21.0 & 25.0 & 25.4 \\
\hline$C_{b e d}\left(\mathrm{~g} \mathrm{l}^{-1}\right)$ & 3.2 & 7.1 & 10.7 & 17.3 & 20.5 & 22.3 & 24.7 & 29.1 & 33.8 & 47.0 & 50.1 & 53.3 & 50.8 & 73.9 & 80.7 \\
\hline$C_{10 \mathrm{cmab}}\left(\mathrm{g} \mathrm{l}^{-1}\right)$ & 1.51 & 2.26 & 1.93 & 2.06 & 2.89 & 5.75 & 6.98 & 2.71 & 3.08 & 6.52 & 9.94 & 9.12 & 4.43 & 4.45 & 3.99 \\
\hline$C_{30 \mathrm{cmab}}\left(\mathrm{g} \mathrm{l}^{-1}\right)$ & 0.93 & 1.31 & 1.74 & 1.15 & 1.87 & 4.79 & 5.58 & 1.59 & 2.22 & 5.38 & 8.62 & 8.01 & 3.61 & 2.78 & 2.56 \\
\hline$\%$ sand $_{\text {bed }}$ & 13.0 & 28.6 & 5.3 & 43.8 & 41.2 & 27.0 & 48.4 & 47.1 & 34.5 & 56.3 & 41.0 & 47.3 & 78.1 & 56.7 & 67.7 \\
\hline$\%$ silt $_{\text {bed }}$ & $\mathrm{n} / \mathrm{a}$ & $\mathrm{n} / \mathrm{a}$ & 49.0 & 50.8 & 54.5 & 61.9 & 46.6 & 49.7 & 60.1 & 40.4 & 53.6 & 30.9 & 20.1 & 40.4 & 31.2 \\
\hline \%clay ced $_{\text {bed }}$ & $\mathrm{n} / \mathrm{a}$ & $\mathrm{n} / \mathrm{a}$ & 49.7 & 5.4 & 4.3 & 11.1 & 5.0 & 3.2 & 5.4 & 3.3 & 5.4 & 4.3 & 1.8 & 2.9 & 2.3 \\
\hline$\%$ sand $_{10 \mathrm{cmab}}$ & 0.0 & 0.0 & 0.0 & 0.0 & 4.2 & 2.1 & 2.3 & 0.0 & 3.9 & 2.9 & 5.1 & 4.4 & 2.0 & 0.0 & 3.8 \\
\hline$\%$ sand $_{30 \mathrm{cmab}}$ & 0.0 & 0.0 & 0.0 & 0.0 & 0.0 & 1.3 & 2.0 & 0.0 & 0.0 & 1.5 & 4.6 & 3.0 & 0.0 & 0.0 & 0.0 \\
\hline$\overline{\mathrm{D}_{50}}(\mu \mathrm{m})$ & $\mathrm{n} / \mathrm{a}$ & $\mathrm{n} / \mathrm{a}$ & $\mathrm{n} / \mathrm{a}$ & 21.2 & 33.6 & 25.0 & 34.4 & 34.3 & 35.8 & 66.3 & 36.6 & 48.3 & 60.7 & 59.1 & 61.6 \\
\hline$\eta(\mathrm{cm})$ & 0.86 & 1.22 & 0.20 & 1.30 & 0.60 & 0.50 & 0.50 & 0.75 & 0.65 & 0.75 & plane & 1.10 & 0.43 & 0.68 & 0.75 \\
\hline$\lambda(\mathrm{cm})$ & 8.29 & 6.70 & 6.00 & 13.00 & 7.58 & $?$ & 8.00 & 8.25 & 7.00 & 9.25 & plane & 9.10 & 7.83 & 9.60 & 7.50 \\
\hline$\delta_{b l}(\mathrm{~cm})$ & 2.49 & 0.95 & 1.04 & $?$ & 1.63 & 0.80 & $<0.3$ & $<0.3$ & $<0.3$ & $<0.3$ & $<0.3$ & $<0.3$ & $<0.3$ & $<0.3$ & $<0.3$ \\
\hline$\delta_{g m}(\mathrm{~cm})$ & 1.87 & 2.64 & 1.50 & 2.13 & 2.62 & 2.33 & 3.01 & 2.33 & 2.04 & 2.59 & 1.20 & 2.92 & 2.41 & 2.27 & 2.11 \\
\hline $\mathrm{Ri} \times 10^{2}$ & $\mathrm{n} / \mathrm{a}$ & $\mathrm{n} / \mathrm{a}$ & $\mathrm{n} / \mathrm{a}$ & 3.10 & 2.84 & 2.69 & 2.38 & 3.57 & 3.89 & 1.55 & 1.53 & 1.81 & 2.60 & 4.99 & 4.96 \\
\hline$H_{V M}(\mathrm{~cm})$ & 17.9 & 21.0 & 14.5 & 19.7 & 15.1 & 16.3 & 16.9 & 13.7 & 11.2 & 11.5 & 6.4 & 16.5 & 8.9 & 8.8 & 8.5 \\
\hline$u_{* g m}\left(\mathrm{~cm} \mathrm{~s}^{-1}\right)$ & 4.79 & 5.28 & 3.92 & 7.61 & 5.32 & 6.05 & 6.11 & 5.83 & 6.34 & 8.12 & 4.74 & 10.61 & 6.20 & 7.02 & 7.56 \\
\hline
\end{tabular}

Refer to list of notation for symbol definitions. Experiments 1-3 did not produce definable HDS.

\section{Sediment Experiments}

A series of fifteen experiments were performed in which the false floor was replaced with a 15 -cm-thick sediment bed, and the U-tube was filled with fresh water. The sediment mixture was composed of crushed silica silt with a mean particle size of $\sim 26 \mu \mathrm{m}$ (Fig. 2). The predominantly siltsize mixture contained approximately $10 \%$ clay $(D<3.9 \mu \mathrm{m})$ and $20 \%$ sand $(D>63 \mu \mathrm{m})$.

Initial Bed Placement.-To begin an experiment, dry sediment was added to the test section and the U-tube was slowly filled with freshwater. Initially, the wave oscillations caused the sediment bed to liquify and spread laterally in the test section until it was of uniform thickness and the surface of the bed was smooth and level. The bed appeared liquefied for $\sim 10$ minutes, because it shifted back and forth on the order of a centimeter

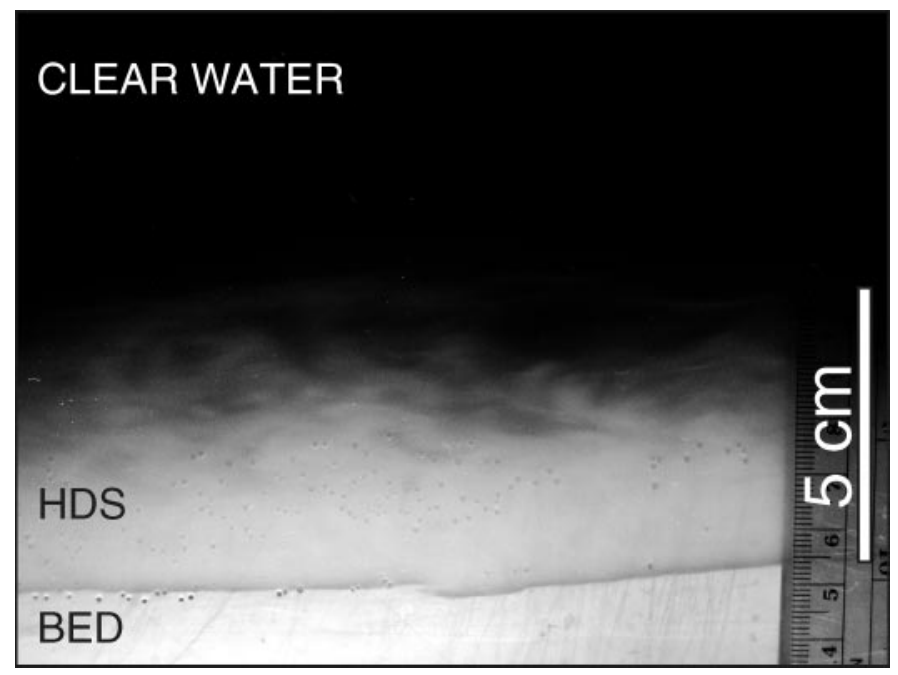

FIG. 3.-Photograph of the high-density suspension from experiment S9. The sediment was white. The lighting was from below and at an angle to maximize the visibility of the HDS. The clear water region above the HDS was dilute in comparison to the HDS, but still had sediment concentrations of $\sim 2-3 \mathrm{~g} / \mathrm{l}$ (Table 1). Note the strong turbulent deformation in the HDS and the patchiness of the suspended sediment. The actual patchiness was greater than what appears in the photograph because of smearing during the exposure time. in response to changes in pressure induced by the piston. During the liquefaction period, sediment and pore water was funneled from the bed to the sediment-water interface through a series of quasi-periodic (spaced on the order of $10 \mathrm{~cm}$ ) conduits in the liquefied bed. We did not observe sorting of the bed sediment as a result of this process.

New sediment was added to the test section every third or fourth experiment to account for the loss of sediment to the end tanks and to maintain the sediment bed with a uniform thickness of $10-15 \mathrm{~cm}$. Bed liquefaction did not occur at the beginning of every experiment, but only when new sediment was added to the test section. For the experiments that did not have newly added sediment, the order of the experiments was set such that each experiment had wave conditions that produced a higher bed shear stress than the previous. This allowed the sorted deposit from a previous run to be easily eroded within the first several minutes of a new experiment, so that the suspensions were not affected by the initial bed conditions.

High-Density Suspensions.-For most of the experiments, a dense layer of suspended sediment became visible above the bed a few minutes after a run commenced (with or without liquefaction), indicating rapid entrainment of sediment (Figs. 3, 4). These HDS had depth-averaged concentrations $\left(C_{\text {ave }}\right)$ ranging from $6 \mathrm{~g} / \mathrm{l}$ to $25 \mathrm{~g} / \mathrm{l}$ and near-bed sediment concentrations $\left(C_{b e d}\right)$ greater than $10 \mathrm{~g} / \mathrm{l}$ and as high as $80 \mathrm{~g} / \mathrm{l}$ (Table 1). Despite high sediment concentrations, HDS were turbulent, with dominant eddies switching directions with the wave oscillations. The suspensions were separated from the upper water column by a lutocline typically $2-8 \mathrm{~cm}$ above the bed (cmab) (Table 1). The suspensions appeared to be in a quasi-steady state because they did not change significantly in thickness or in sediment concentration for the duration of an experiment ( $\sim 90 \mathrm{~min})$. In fact, they did not even change thickness as they moved over the ripples on the bed, giving the lutocline an undulating appearance. Experiments with higher $\mathbf{R}$, $U_{o r b}$, and bed shear $\left(u_{* g m}\right)$ produced suspensions with higher sediment concentrations (Fig. 5). Experiments 1, 2, and 3, which did not produce definable lutoclines, had lower values of $\mathbf{R}\left(<7.5 \times 10^{4}\right), U_{\text {orb }}(<29 \mathrm{~cm} /$ $\mathrm{s})$, and $C_{\text {bed }}(<11 \mathrm{~g} / \mathrm{l})$.

Vertical sorting in the water column caused many of the HDS to be enriched in sand with respect to the original bed, especially near the bed. For example, in experiment S13 the sediment was mostly mud (silt + clay) above the lutocline (Figs. 6, 7). Near the lutocline the proportions of sand and mud approached that of the bed (i.e., 20\% sand and $80 \%$ mud) (Fig. 7). Below the lutocline, the increase in total sediment concentration was almost entirely due to the sand fraction. This vertical sorting resulted in 


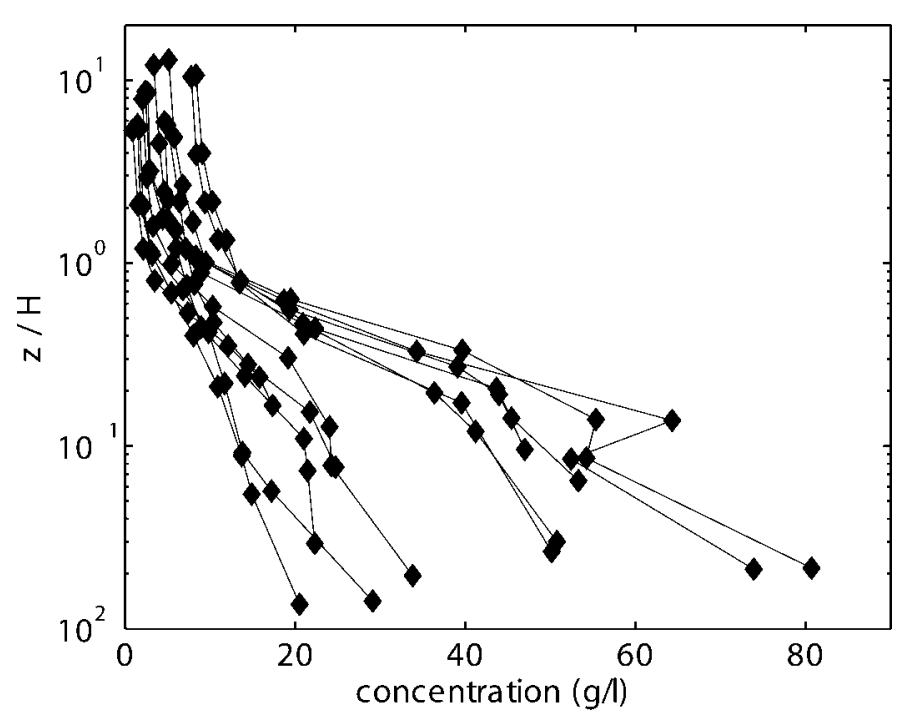

FIg. 4.-Vertical profiles of sediment concentration from all of the experiments that had HDS (experiments S4-S15). The height above the bed (z) is nondimensionalized by the height of the lutocline for each experiment.

nearly $40 \mathrm{~g} / \mathrm{l}$ of suspended sand near the bed, which constituted $\sim 80 \%$ of the near-bed suspended load. Near-bed coarsening occurred for all of the experiments; however, it was most profound in experiment S13 (Table 1). The near-bed sand content ranged from 27 to $78 \%$ for all the experiments with HDS, while the depth-averaged grain size inside the HDS remained silty $\left(21<\overline{D_{50}}<66\right)$. Thicker HDS tended to be less concentrated and finer-grained, while thinner HDS were more concentrated and coarsergrained (Fig. 8).

Deposits from High-Density Suspensions.-At the end of each experiment, the waves were stopped and the sediment was allowed to settle for approximately 24 hours. Every experiment left a thin deposit $(<0.5 \mathrm{~cm})$, which draped the bed uniformly and appeared overall normally graded (Fig. 9). The lowermost part of the deposit was the coarsest and probably resulted from a traction layer. Many of the deposits appeared to consist of two normally graded beds that were stacked one on top of another, but deciphering this level of detail was possible only for the thicker deposits. The origin of these two layers is discussed below.

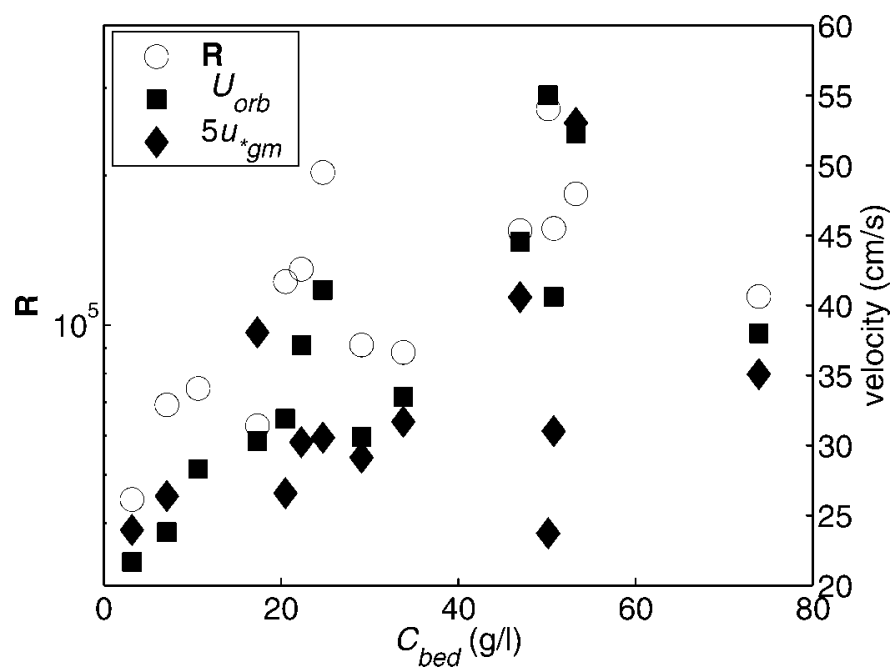

FIG. 5.-Comparison of the near-bed sediment concentration $C_{b e d}$ with the orbital velocity $U_{o r b}$, Reynolds number $\mathbf{R}$, and modeled shear velocity $u_{* g m}$ calculated from the Grant and Madsen (1979) wave-boundary-layer model.

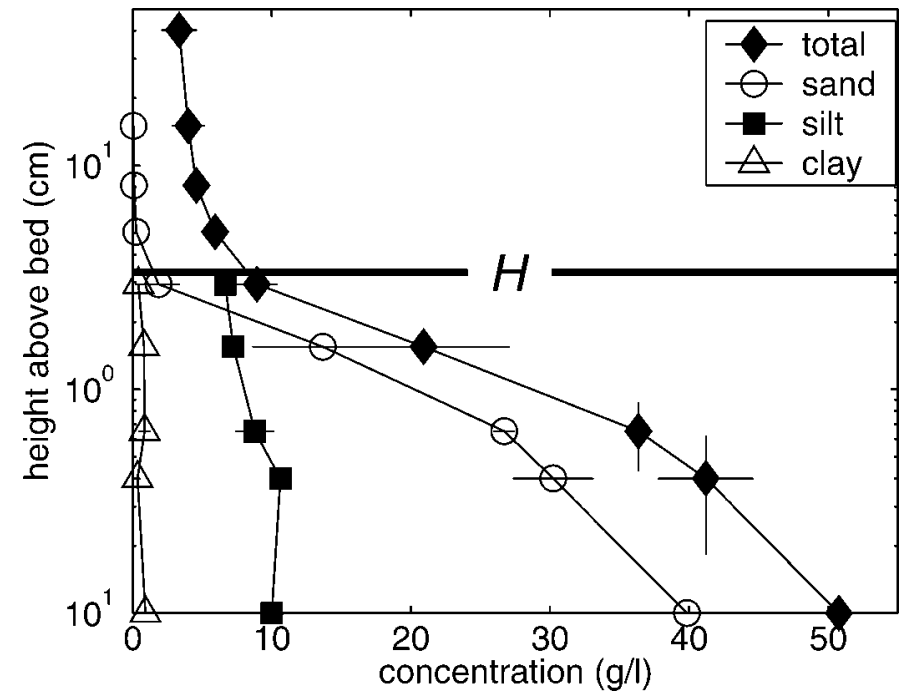

Fig. 6.-Vertical profile of clay, silt, sand, and total sediment concentration for experiment S13. Experiment S13 is used as an example experiment because it had a highly concentrated suspension with a well developed lutocline. The profiles shown are the average of two measured profiles separated by approximately 60 minutes. The horizontal error bars represent the standard deviation between these two profiles. Note the small difference between the two profiles, indicating that the HDS were in a quasi-steady state. The vertical error bars on the total concentration profile represent the average ripple height for this experiment. The profiles of silt and clay do not extend above the lutocline $(H)$ because the samples were too small to separate silt from clay.

Wave Ripples.-Coincident with the formation of a high-density suspension was the coarsening of the top $\sim 0.2 \mathrm{~cm}$ of the bed. Fine sediment was suspended in the HDS while the coarsest sediment remained on or very near the bed. Some of this coarse fraction moved in saltation, resulting in ripples (Fig. 10). The bed shear stress was high enough in experiment S11 such that it resulted in plane-bed conditions. After each experiment, measurements were taken of ripple heights, measured trough to crest, and wavelengths, which then were averaged to give a mean ripple height and mean ripple wavelength for each experiment. The ripples had heights rang-

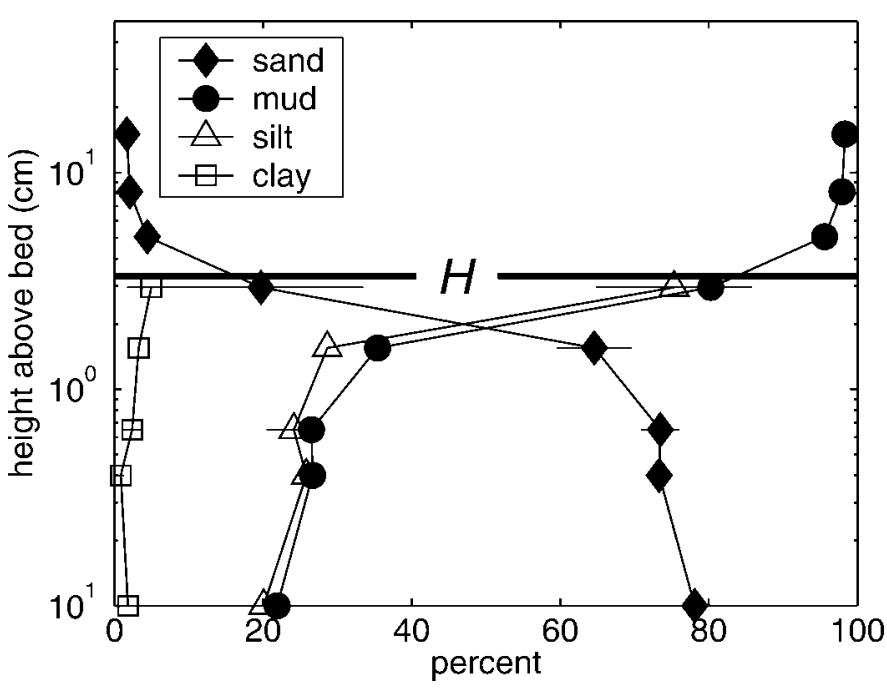

FIG. 7.-Vertical profiles of the percent of clay, silt, mud, and sand from experiment S13. Experiment S13 is used as an example experiment because it had a highly concentrated suspension with a well developed lutocline. The samples taken above $H$ were too small to split into clay and silt, and are therefore shown as percent mud (=clay + silt). The top of the HDS is denoted by $H$. 


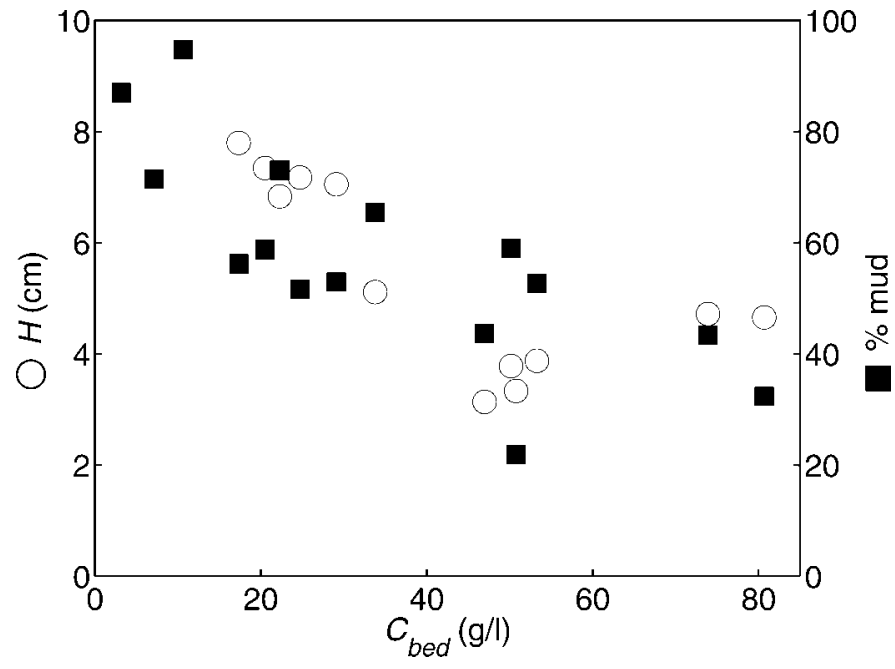

FIG. 8. - Comparison of the near-bed percent of mud (silt + clay), the height of the lutocline $H$, and the near-bed sediment concentration $C_{b e d}$ for all the sediment experiments with definable $H$. Note that the depth-averaged concentrations and grain sizes within the HDS were smaller than the near-bed values shown on this figure (Table 1).

ing from 0.2 to $1.3 \mathrm{~cm}$ and wavelengths from 6 to $13 \mathrm{~cm}$, with a trend of increasing ripple height with increasing wavelength (Table 1). At the end of each experiment, after the suspended sediment settled, the resulting deposit overlay coarser sand lenses from the ripples (Fig. 10). Several of these sand lenses were sampled, and the average grain size for most ripples was approximately $70 \mu \mathrm{m}$ (Fig. 2), which was significantly coarser than the mean grain size of the bulk sediment $(\sim 26 \mu \mathrm{m})$. The size of the ripples did not show any correlation with the thickness or the concentration of the HDS.

Asymmetric Bed Scours.-During experiment S11, which had planebed conditions, the bed developed asymmetric scours (Fig. 11). These scours often developed when the flow partially eroded through a resistant cohesive layer in the bed and then undermined the less resistant sediment below. Scours were short lived and usually filled in within a few minutes.

\section{Saline Experiment}

In order to illustrate the importance of particles in HDS, one saline experiment was performed and analyzed qualitatively. This experiment used dense brine in place of a sediment suspension to identify the interactions between a near-bottom density interface and oscillatory flow in the absence of particles. A high-density salt solution (density $\sim 1100 \mathrm{~kg} / \mathrm{m}^{3}$, equivalent to a sediment concentration of $\sim 161 \mathrm{~g} / \mathrm{l}$ ) was dyed and poured into the empty U-tube until a layer thickness of approximately $15 \mathrm{~cm}$ was achieved. The rest of the U-tube was slowly filled with fresh tap water (density $\sim 1000 \mathrm{~kg} / \mathrm{m}^{3}$ ). A sharp interface (i.e., pycnocline) developed between the saline layer and the fresh ambient water because of the density stratification

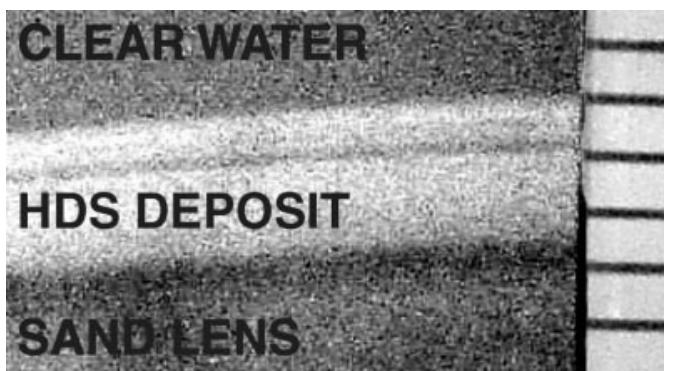

FIG. 9.-Close-up photograph of the deposit from experiment S15. Scale on right is in $\mathrm{mm}$. Coarse sediment appears darker than fine sediment in the photograph. The deposit from the suspension overlay a coarse sand lens from a ripple. The very top of the sand lens was the coarsest region in the photograph. The deposit from the high-density suspension in this experiment appeared to consist of two stacked normally graded beds. The lower bed was approximately $2 \mathrm{~mm}$ thick and the upper bed was approximately $1 \mathrm{~mm}$ thick. The two beds can be distinguished in the photograph by the very thin coarse layer that separated them. This coarse layer was interpreted to be the base of the upper bed. The top of the upper bed was at the sediment-water interface. The clear water above the upper bed appears dark gray in the photograph as a result of the lighting.

(Fig. 12A). Immediately after modest waves were imposed $\left(T_{w}=5 \mathrm{~s}, U_{\text {orb }}\right.$ $=18 \mathrm{~cm} / \mathrm{s}$ ), the brine began to mix with the ambient fluid. Internal waves developed on the pycnocline (Fig. 12B), and within approximately 25 minutes the salty layer visually "mixed out" (Fig. 12C). That is, the brine that was originally concentrated at the bottom of the wave tank became distributed evenly throughout the water column. Apparently, brine is not able to maintain a quasi-steady state like the suspensions.

\section{DISCUSSION}

\section{Bed Liquefaction}

Bed liquefaction commonly occurs when loosely packed grains shift into a more compact structure through vibrations resulting from shaking or other stresses (Seed 1968). If the bed consolidates faster than the pore fluid can escape, the pore pressure can exceed the overburden pressure, resulting in liquefaction. In marine environments, waves can consolidate a bed from normal stresses compacting the structure and shear stresses causing grains to shift into more stable positions (Verbeek and Cornelisse 1997).

In our experiments, bed liquefaction only occurred during the runs that began with a new sediment bed. Because the sediment was added rapidly to the U-tube, the initial grain structure of the bed was loosely packed. For these experiments, liquefaction occurred instantaneously with the onset of wave forcing and lasted for $\sim 10$ minutes. Liquefaction is expected to be short lived, because as the pore fluid escapes the bed, the grains form a more stable structure (Middleton 1969). Once the bed was liquefied, subsequent experiments did not cause liquefaction because the bed was already in a stable configuration. As previously stated, the pore pressure was relieved in the liquefied bed through small quasi-periodic conduits that fed fluidized sediment and pore fluid to the sediment-water interface. Such

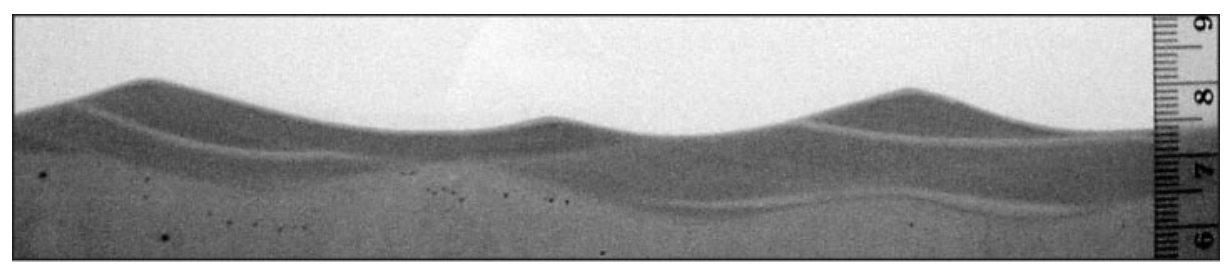

FIG. 10.-Photograph of ripples from experiment S15. Coarser sediment appears darker in the photograph. Note that the ripples were coarser than the undisturbed sediment near the bottom of the photograph, and they were coarser than the deposit from the suspension that draped the top of the ripples. Most of the deposit from the previous experiment was reworked during experiment S15. However, the light bands of sediment below the ripples were remnants from this previous deposit. Scale on right is in centimeters. 


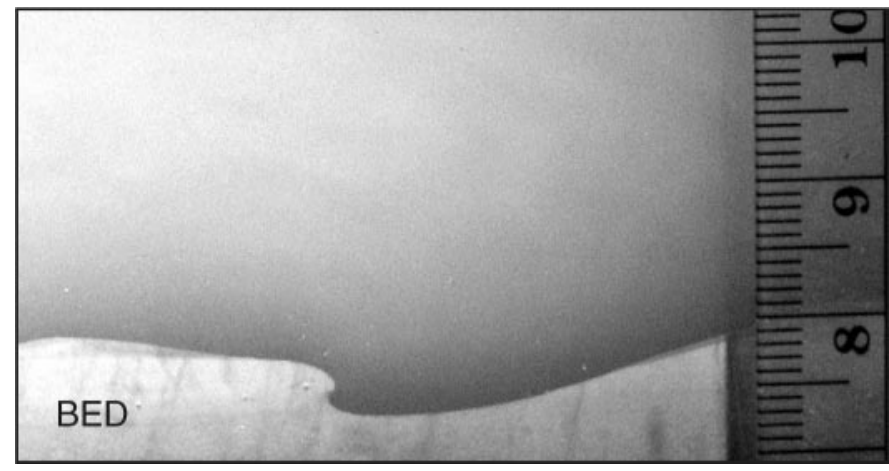

FIG. 11.-Photograph of an asymmetric bed scour from experiment S11. Scale on right is in centimeters.

conduit-like structures have been documented extensively in the geologic record (Leeder 1999).

It has been hypothesized that significant sediment transport on continental shelves is due to wave-loaded liquefied beds that flow down slope under the influence of gravity (Myrow and Hiscott 1991; Puig et al. 2004; Walker 1984). Our experiments are consistent with the idea that liquefaction can occur in unconsolidated silt-size sediment when loaded by oscillatory forcing. Such high-porosity beds $(60-80 \%)$ beds are common in the upper Eel Canyon (Lomnicky, T.D., Nittrouer, C.A., and Mullenbach, B.L., unpublished work), where gravity-driven benthic suspensions have been observed (Puig et al. 2004). However, the initial placement of the sediment bed in our experiments was different than natural deposition and might have made the bed more prone to liquefaction.

\section{Wave Ripples}

It is often assumed that ripples are unlikely to form in exclusively siltsize sediments (e.g., Wiberg and Harris 1994) because bedload transport is required to form ripples and the shear stress needed to initially move fine sediment is also usually sufficient to suspend it. In our experiments, the segregation of silt and sand in HDS allowed the initially silty bed $\left(D_{50}=\right.$ $26 \mu \mathrm{m})$ to rapidly coarsen and form ripples. Although the ripples were coarser than the original bed mixture, they still contained a significant particle fraction finer than sand ( 40\%; Fig. 2).

Wave ripples are commonly classified as orbital or anorbital ripples. Orbital ripples have wavelengths $\lambda$ that are dependent on the orbital diameter $\left(d_{0}=2 A\right)$ and anorbital ripples do not (Clifton 1976). Wiberg and Harris (1994) defined orbital and anorbital ripples based on the dimensionless ratios of orbital diameter and ripple height $\eta$, such that $d_{0} / \eta>100$ are anorbital ripples and $d_{0} / \eta<20$ are orbital ripples. For $20<d_{0} / \eta<$ 100 , the ripples are classified as suborbital ripples. The ripples in our experiments had an average $d_{0} / \eta$ value of 103 with a standard deviation of 70 , and therefore are classified as anorbital and suborbital ripples. Wiberg and Harris (1994) then combined data sets on wave ripples from several field and laboratory studies and found that most of the orbital ripples collapsed onto the line $\lambda=0.62 d_{0}$. In contrast, most of the anorbital ripples had $\lambda / D \approx 530$, but with significant scatter. $\lambda / \mathrm{D}$ for our experiments was 1200 with a standard deviation of 255 , where $D$ was taken to be $70 \mu \mathrm{m}$ (Fig. 2). The ripples in these experiments did not fall on either line, and therefore are probably best classified as suborbital ripples (Fig. 13).

Because $D$ and $d_{0}$ are usually known and $\lambda$ can be calculated from Figure 13, Wiberg and Harris (1994) developed a model based on a curve-fit of data from previous studies for calculating $\eta$ :

$$
\frac{\eta}{\lambda}=\exp \left[-0.095\left(\ln \frac{d_{0}}{\eta}\right)^{2}+0.442 \ln \frac{d_{0}}{\eta}-2.28\right]
$$
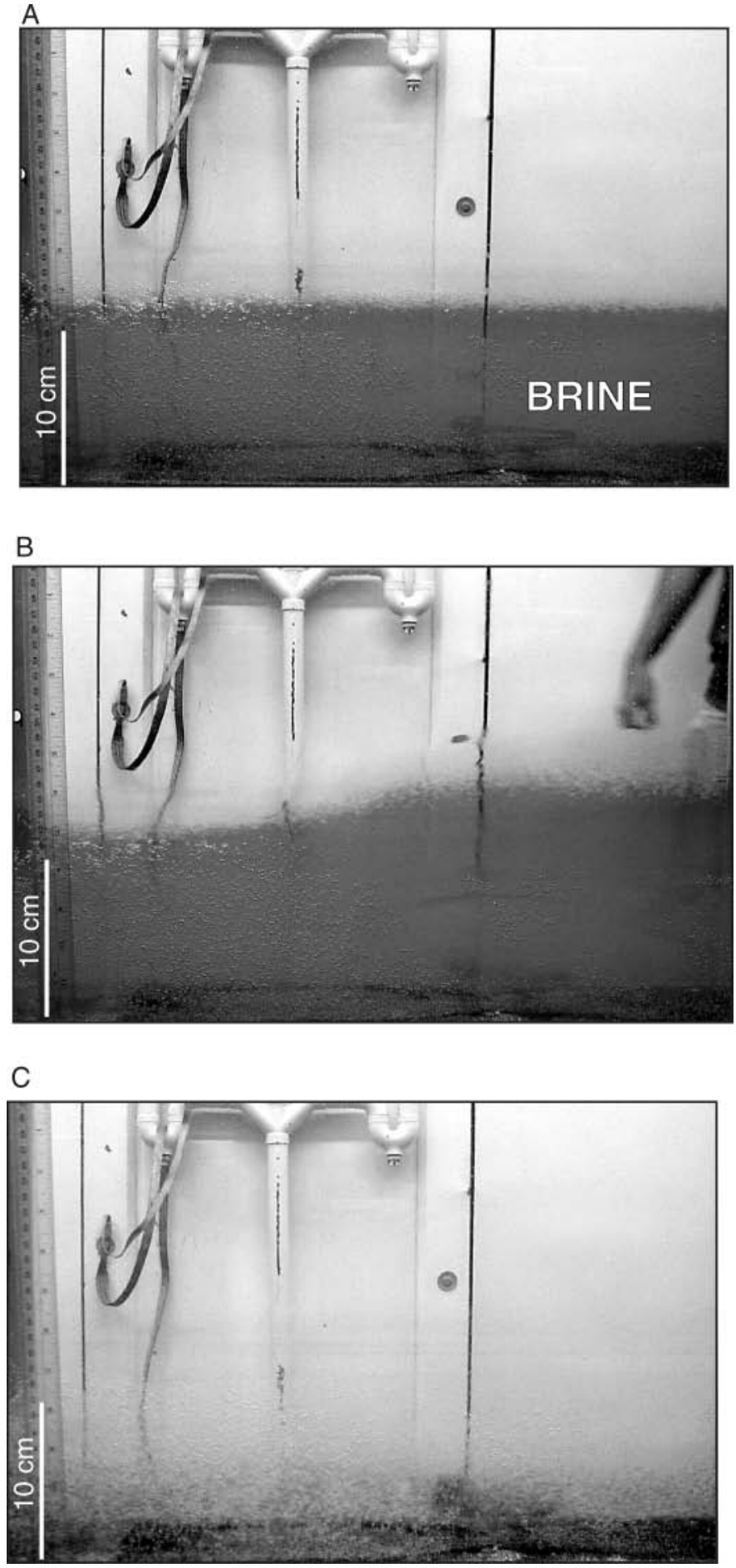

FIg. 12.-A) Photograph of the initial conditions in the saline experiment. A dense brine $\left(\rho=1.1 \mathrm{~kg} / \mathrm{m}^{3}\right)$ was dyed and poured into the U-tube. The rest of the U-tube was filled with fresh tap water. B) Photograph of the saline experiment seconds after the wave forcing $\left(T_{w}=5 \mathrm{~s}\right.$., $\left.U_{\text {orb }}=18 \mathrm{~cm} / \mathrm{s}\right)$ commenced. Note the internal wave on the interface between the brine and the fresh water above. C) Photograph of the saline experiment after approximately 25 minutes. Note that the brine visually mixed throughout the water column. 


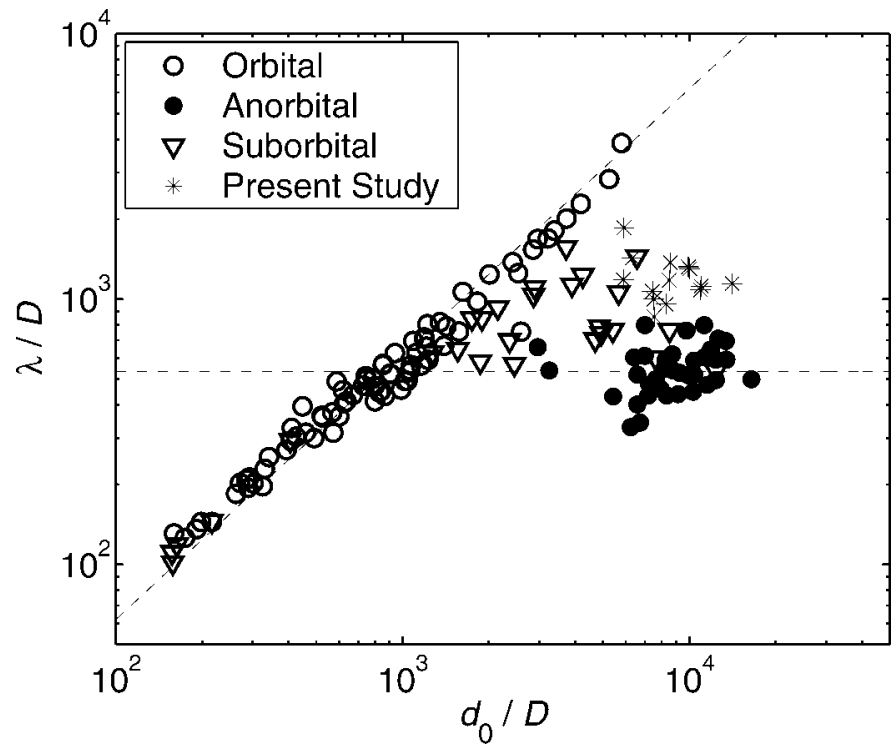

FIG. 13.-Comparison of nondimensional ripple wavelength $\lambda / D$ and nondimensional orbital diameter $d_{0} / D$ modified from Wiberg and Harris (1994). The orbital, anorbital, and suborbital ripples, which are data of previous studies compiled and classified by Wiberg and Harris (1994), are shown along with the ripples from the present study. For our study $D$ was estimated as $70 \mu \mathrm{m}$ (Fig. 2). Wiberg and Harris (1994) found that most of the orbital ripples collapsed on the line $\lambda=0.62 d_{0}$ (shown on figure) and most of the orbital ripples collapsed on the line $\lambda / D=530$ (shown on figure). The data from previous studies compiled by Wiberg and Harris (1994) are from Carstens et al. (1969), Kennedy and Falcón (1965), Mogridge and Kamphuis (1972), Dingler (1974), and Inman (1957).

The ripples in our experiments are in agreement with Equation 1 (Fig. 14). Despite the complex interactions between wave boundary layers and HDS, ripple geometry from our experiments is consistent with previous studies that did not observe HDS.

\section{Asymmetric Bed Scours}

The formation of flute-like scours in experiment S11 has important implications for interpreting the sedimentary record. In marine environments, flutes are typically associated with strong unidirectional currents (Myrow and Southard 1996), which is consistent with laboratory experiments (e.g., Dzulynski and Sanders 1962). However, the interpretation that flutes result exclusively from unidirectional currents has been called into question because flutes are also found on beds interpreted to have been deposited in wave-dominated shelf environments (Hamblin and Walker 1979). These experiments provide evidence that asymmetric scours resembling flutes can form in oscillatory flow without a mean current. The asymmetry of the scours likely did not result from the slight mean current $(<3 \mathrm{~cm} / \mathrm{s})$ produced by overflow in the piston chamber (see Experimental Facility section) because the asymmetry of the scours was not preferentially orientated in either the upstream or downstream directions with respect to this current. A more thorough study on scours in oscillatory flows is needed before these observations can be used in analyzing sedimentary deposits because the asymmetric scours in our study only formed in experiment S11, and they were few, short lived, and varied in direction and morphology.

\section{Formation of High-Density Suspensions}

Before comparing our experiments to currently used models on the formation of HDS, it is useful to summarize the results of Lamb et al. (2004). Their paper presented high-resolution velocity measurements from these same experiments, which revealed that the wave boundary layer $\delta_{b l}$ (measured as the height above the bed where the fluid velocity begins to de-

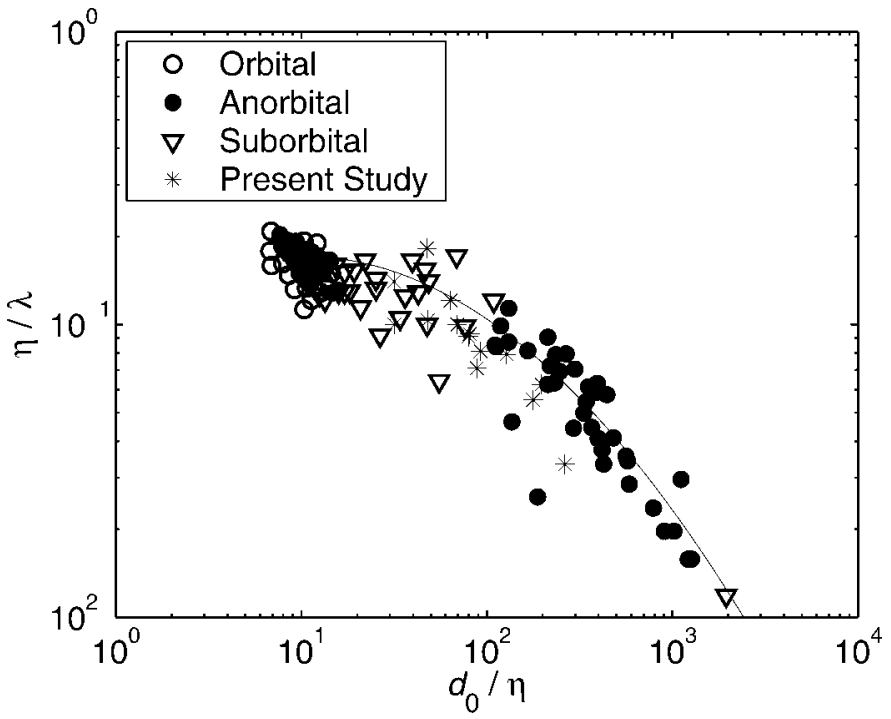

FIG. 14.-Comparison of nondimensional ripple steepness $\eta / \lambda$ and nondimensional orbital diameter $d_{0} / \eta$ modified from Wiberg and Harris (1994). The orbital, anorbital, and suborbital data were from previous studies compiled by Wiberg and Harris (1994) (Fig. 13). The curve is a second-order polynomial fit to the steepness data from Wiberg and Harris (1994) and is given by Equation 1.

crease from the free-stream velocity because of viscous effects imposed by the bed), while typically greater than $1 \mathrm{~cm}$ thick in sediment-free conditions, was reduced substantially in size (often to less than $3 \mathrm{~mm}$ ) in experiments with HDS (Table 1). This likely resulted from sediment-induced stratification, which limited vertical mixing of momentum. This hypothesis was supported by a nearly critical value of a flux Richardson number, which indicates that stratification was important in limiting momentum exchange. However, as shown in our study, the flows were still able to support suspensions as thick as $8 \mathrm{~cm}$, well outside of the boundary layer. A turbulent kinetic energy budget revealed that energy was transported from this thin boundary layer region (where it was produced) higher into the water column where it was able to suspend sediment (Lamb et al. 2004). Thus, in our experiments it does not appear that HDS were trapped within the wave boundary layer as other studies have suggested (e.g., Traykovski et al. 2000; Wright et al. 2001).

Thickness of High-Density Suspensions. - In the literature the lutocline height is often measured as the elevation where the concentration $=10 \mathrm{~g} /$ $1\left(H_{10}\right)$ (Table 1) (Trowbridge and Kineke 1994; Kineke et al. 1996; Traykovski et al. 2000). However, in our experiments $H$ (elevation where concentration $=0.1 C_{b e d}$ ) better served to characterize the lutocline on the basis of comparison with the concentration profiles (Fig. 4) and visual observations (e.g., Fig. 3). While $H$ and $H_{10}$ were in good agreement for some of the experiments, $H_{10}$ underestimated the lutocline height for experiments with lower sediment concentrations (Table 1). This resulted because the low concentration HDS (S4-S8) were thick, but had concentrations of $10 \mathrm{~g} / \mathrm{l}$ only very near the bed. Assuming $H=H_{10}$ would have resulted in data trends opposite to those shown in Figure 8. That is, for HDS with higher sediment concentrations and sand contents, $H_{10}$ increases while $H$ decreases (Table 1$)$.

The height of HDS has not been modeled extensively. Traykovski et al. (2000) observed that $H$ scaled with a modeled sediment-free wave-boundary-layer height $\delta_{g m}=A\left(f_{w} / 8\right)^{1 / 2}$, where the friction factor $f_{w}$ can be calculated from a boundary-layer model (e.g., Grant and Madsen 1979). Another model for calculating $H$ was proposed by Vinzon and Mehta (1998), $H_{V M}$. Following on the work of Huppert et al. (1995), they estimated $H_{V M}$ using a turbulent energy balance and several simplifying assumptions as 


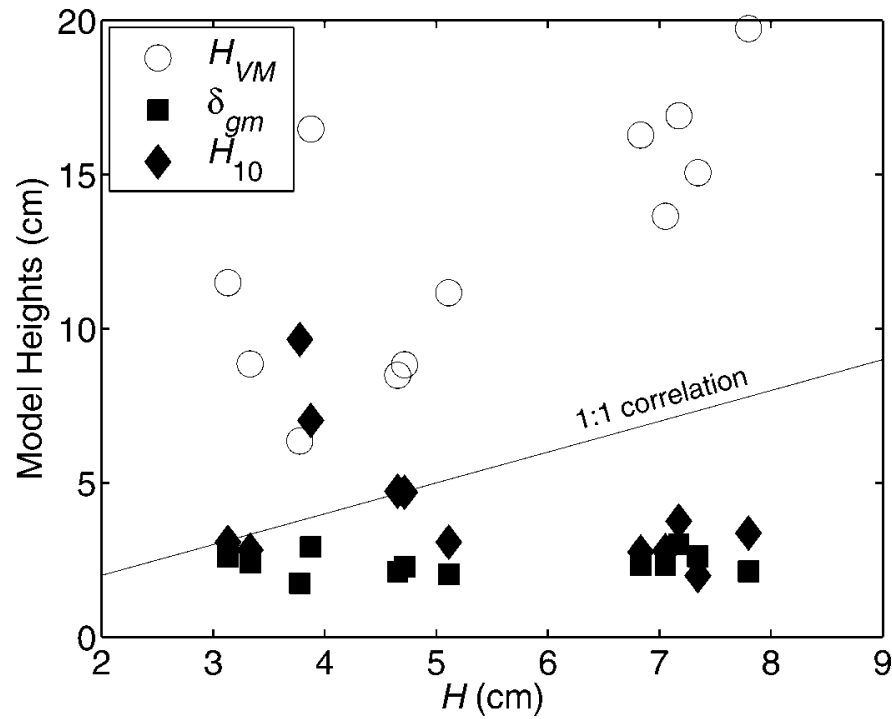

FIG. 15.-Comparison between the lutocline height measured in these experiments $H$ with the linearly interpolated height where the concentration equaled $10 \mathrm{~g} / \mathrm{l}$, and the model heights calculated from Grant and Madsen (1979) $\delta_{g m}$ and Vinzon and Mehta (1998) $H_{V M}$. The line represents a 1:1 correlation.

$$
H_{V M}=0.65\left[\frac{\left(A^{3} k_{s}\right)^{3 / 2}}{T^{3} \operatorname{Rg} C_{a v e} w_{s}}\right]^{1 / 4}
$$

where $g$ denotes the acceleration due to gravity, $w_{s}$ denotes the sediment settling velocity (calculated using Stokes' Law and $\overline{D_{50}}$ for our experiments $)$, and $R$ is the relative excess density of the sediment; $R=\left(\rho_{s}-\right.$ $\left.\rho_{w}\right) / \rho_{w}$, where $\rho_{\mathrm{s}}$ is the density of sediment and $\rho_{\mathrm{w}}$ is the density of water. While it is encouraging that these models bound the data (Fig. 15), neither has shown predictive capability for our experiments. A more appropriate model might be one that is based on a length scale of transport of turbulent kinetic energy, because it was this transported energy that supported the suspension.

Development of Quasi-Steady Suspensions.-Our measurements and visual observations indicate that the HDS were in a quasi-steady state with respect to $H$ and sediment concentration after the first few minutes of each experiment. In order for a suspension to be at steady state, the entrainment of sediment $(E)$ must balance the settling of sediment $(S)$. We observed entrainment occurring through turbulent bursts that transported sediment from the bed up into the water column when the orbital velocity was greatest. Settling occurred when the velocity switched directions and the orbital motions temporarily went to zero. Because the size of the sediment in the HDS was of silt to sand size, individual particle settling was not negligible. However, the particles often appeared to settle collectively as concentrated patches of slurry (e.g., Kuenen 1968; McCool and Parsons 2004), not as discrete particles (note the patchiness in Fig. 3). The importance of particle settling in maintaining steady suspensions is further emphasized by the comparison with the salt experiment, where the brine did not reach a steady state in thickness or in concentration despite significant stratification.

Together, on the timescale of the wave period, the sediment-rich bursts during high orbital velocities and the settling of particles as the orbital velocity approached zero gave the HDS an appearance of breathing. That is, the lutocline height rose and fell temporally within each wave oscillation, although asymmetry was common. Because of breathing, the lutoclines were visually much sharper at any instant in time (e.g., Fig. 3) than they appear in our temporally averaged concentration profiles (Fig. 4). Traykovski et al. (2000) also observed a temporally undulating lutocline on the Eel shelf, but they attributed the phenomenon to internal waves. We did not observe internal waves in our experiments, though our qualitative observations are consistent with those made by Traykovski et al. (2000).

Here, we seek a simple relationship to predict suspended sediment load on the basis of properties of the flow. Stratified flows are often described using a bulk Richardson number of the form (Turner 1973)

$$
\mathrm{Ri} \equiv g^{\prime} L / U^{2}
$$

where $U$ and $L$ are characteristic velocity and length scales of the flow. $g^{\prime}$ is the buoyancy term, e.g., $g^{\prime}=R C_{\text {ave }} g$ for sediment suspensions.

Wright et al. (2001) postulated that HDS should tend to an equilibrium capacity of suspended sediment for a given level of turbulence in the flow because of a dynamic feedback, which can be described using a constant critical value of the bulk Richardson number $\left(\mathrm{Ri}_{\mathrm{c}}\right)$. If the suspension is perturbed from equilibrium by increasing the level of turbulence, the flow temporarily becomes undersaturated with sediment. In response, the increased turbulence erodes sediment from the bed, therefore returning the suspension to its equilibrium capacity. If the suspension is perturbed from equilibrium by decreasing the level of turbulence, the flow becomes oversaturated with sediment, causing the sediment to settle, and returning the suspension to equilibrium. Wright et al. (2001) set $L=H$ and $U=U_{\max }$, on the basis of a comparison with a gradient Richardson number, to arrive at

$$
\mathrm{Ri}=\mathrm{Ri}_{\mathrm{c}}=R C_{\text {ave }} g H / U_{\max }^{2}
$$

where $U_{\max }$ is the vector mean of the velocity forced by currents, waves, and gravity $\left(U_{\max }=U_{\text {orb }}\right.$ for our experiments). Our calculated values of Ri were nearly constant with a mean value of $3.0 \times 10^{-2}$ and a standard deviation of $1.2 \times 10^{-2}$ for our experiments with HDS (Table 1).

There are two likely suspension-limiting mechanisms that result in quasisteady HDS that maintain a constant bulk Richardson number: (1) sediment-induced stratification and (2) entrainment of sediment from the bed. Wright et al. (2001) argued that the sediment concentration inside HDS is limited by sediment-induced stratification which suppresses turbulence and therefore the ability of a flow to maintain grains in suspension. Several of our observations support this hypothesis. First, the lutoclines in our experiments indicate that the water column was stratified. Our observations of oversaturation and gravitational collapse of the HDS during lulls in the orbital velocity support a stratification-limited suspension (Winterwerp 2001). In addition, the measurements of Lamb et al. (2004), which revealed a reduction in wave-boundary-layer thickness with increasing sediment concentration, and a nearly critical value of a flux Richardson number, indicate that stratification was significant.

Unfortunately it is difficult to theorize a critical value of a bulk Richardson number for a stratification-limited suspension (Turner 1973). Wright et al. (2001) argued that $\mathrm{Ri}_{\mathrm{c}} \sim 0.25$ based on a scaling analysis with a gradient Richardson number where a critical value of 0.25 is known to exist (Howard 1961; Miles 1961; Turner 1973). Our calculated critical value was approximately an order of magnitude less than this theorized value of 0.25 . This could indicate that the HDS in our experiments were not limited by sediment-induced stratification. Alternatively, it might suggest that the assumptions made in the scaling analysis of Wright et al. (2001) did not encompass the appropriate dynamics of the suspensions in our experiments. For example, the Wright et al. (2001) formulation assumes that turbulence supporting a suspension is locally produced from shear in the boundary layer, thus yielding $U_{\text {orb }}$ as the appropriate velocity scale and a gradient Richardson number as a relevant parameter. This assumption implies that the top of the suspension is equivalent to the top of the wave boundary layer and that there is no transported turbulence above the boundary layer. These assumptions are counter to the measurements of Lamb et al. (2004), who showed that a gradient Richardson number cannot be used to characterize the HDS in our experiments.

A more appropriate velocity scale in formulating a bulk Richardson number might be one that describes the transport of turbulence, rather than 


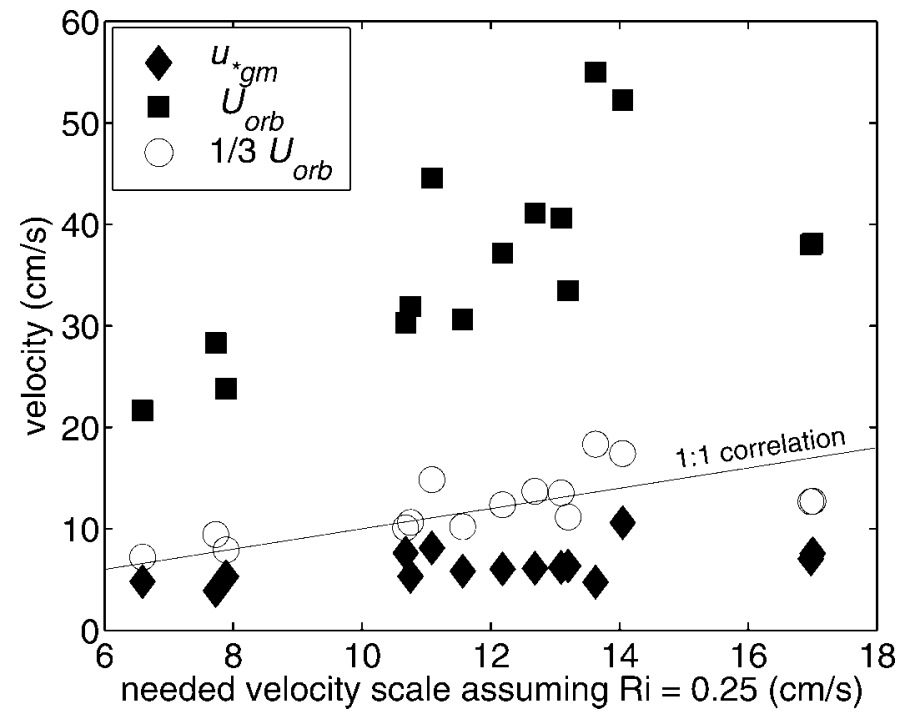

FIG. 16.-Comparison of possible velocity scales for formulating a bulk Richardson number compared to the calculated velocity scale that is needed if the critical value of Ri was 0.25 for our experiments. The assumed velocity scale $U_{\text {orb }}$, as formulated in Equation 3, is much larger than the needed velocity scale. Also, a shear velocity scale $u_{* g m}$ calculated from Grant and Madsen (1979) was too small. $1 / 3 U_{\text {orb }}$ scales reasonably well with the needed velocity scale with $r^{2}=0.67$. The black line in the figure represents a 1:1 correlation with the needed velocity scale.

shear induced by $U_{o r b}$. Using a turbulent velocity scale like $u_{*}$ in place of $U_{o r b}$ in Equation 3 would likely yield critical values of $\mathrm{Ri}_{\mathrm{c}}$ closer to 0.25 . Unfortunately, we were unable to measure $u_{*}$ in our sediment experiments (Lamb et al. 2004). Values of $u_{* g m}$, calculated from the model of Grant and Madsen (1979), were better estimates of the velocity scale than $U_{o r b}$, but they still differ from the needed velocity scale if $\mathrm{Ri}=\mathrm{Ri}_{\mathrm{c}}=0.25$ (Fig. 16). This might be because the Grant and Madsen (1979) model does not include stratification effects in the wave boundary layer. If the bulk Richardson number given by Equation 3 with a critical value of 0.25 is going to be used for modeling HDS similar to our experiments, we suggest a velocity scale of approximately $1 / 3 U_{\text {orb }}$ (Fig. 16), or equivalently $\mathrm{Ri}_{\mathrm{c}} \sim$ 0.03 .

We are unable to rule out the possibility that the HDS were limited by the entrainment of sediment from the bed, rather than stratification. Because we were unable to directly measure the bed stress or the critical bed stress necessary for sediment entrainment, it is difficult evaluate this hypothesis with existing entrainment formulations (e.g., Smith and Mclean 1977; Van Rijn 1984). Nonetheless, it seems reasonable to expect a constant bulk Richardson number for equilibrium suspensions where entrainment from the bed is balanced by near-bed settling because entrainment formulations typically have a quadratic (or nearly quadratic) relationship between sediment concentration and velocity (Smith and Mclean 1977), as does Equation 3.

Winnowing and Armoring.-In our experiments, higher bed shear stresses resulted in both higher concentrations of suspended sediment and coarser suspended sediment (Fig. 8). This was partially a result of bed winnowing. As finer sediment was suspended in the flow, coarser sediment was left behind, so that eventually resuspension was limited to coarser material. It is unclear if bed winnowing favors the entrainment-limited hypothesis or the stratification-limited hypothesis. For example, winnowing might have decreased sediment entrainment from the bed if it was significant enough to armor the bed from further erosion. However, the flows in our experiments were still able to suspend large concentrations of sediment despite winnowing (e.g., Fig. 6).

Alternatively, bed winnowing might have increased sediment-induced stratification by changing the distribution and grain size of sediment in suspension. Higher-energy waves can suspend coarser sediment. However, coarser sediment has a greater settling velocity, so that it cannot be suspended as high in the water column. Therefore, higher-energy conditions produced thinner HDS that were more concentrated and coarser grained (Fig. 8). In this way, minor bed winnowing likely increased stratification effects by allowing increased near-bed concentration gradients, which in turn might have reduced the stratification-governed capacity of the flow.

\section{Deposits from High-Density Suspensions}

An unexpected feature of the deposits that formed at the end of each experiment was that they often consisted of two normally graded beds stacked one on top of another (Fig. 9). The mechanism that formed the two stacked normally graded beds during deposition of a single high-density suspension remains unclear. Our hypothesis is that the first of these beds resulted from a gravitational collapse of the material below the lutocline, while the second bed resulted from slower individual particle settling from the upper water column. If the HDS were gravitationally unstable, a large amount of finer sediment (fine-silt and clay) within the HDS could have been transported to the bed as a plume faster than coarser sediment (coarse silt and sand) from the upper water column (Kuenen 1968). In addition to the two stacked beds, this hypothesis explains our observation that the top of the lower bed was finer than the bottom of the upper bed.

\section{Comparison to Natural Systems}

These experiments were designed to model storm-dominated shelf environments that have easily suspendable, predominantly silt-size sediment. However, care should be taken in applying our experiments to the field. For example, flocculation was not observed because neither salt water nor clay minerals were used in the sediment experiments. In nature, flocculation is important in the upper water column (Sternberg et al. 1999), but it might not be significant in HDS because aggregates break up in the presence of vigorous turbulent fluctuations (Jackson 1995).

In our experiments, some of the sediment suspended above the lutoclines resulted from mixing in the end tanks. In an environment with no source of turbulent energy outside the wave boundary layer, the concentration of suspended sediment in the upper water column $(>20 \mathrm{cmab})$ might have been lower than was found in our experiments. In that case, the suspended silt and clay would be confined closer to the bed, where there was sufficient turbulent energy to maintain grains in suspension; thus sediment sorting in the HDS would not be as profound. However, in most natural environments, tidal currents, storm currents, and internal waves provide sources for background turbulence (e.g., Carter and Gregg 2002). Only small levels of background turbulence are needed in the upper water column to transport clay out of HDS, resulting in coarser HDS. It is important to note that significant sorting occurred within the HDS in our experiments as a result of the boundary-layer processes and not the background turbulence and mixing. For example, the suspension in experiment $\mathrm{S} 4$ had a depth-averaged grain size $(\sim 21 \mu \mathrm{m})$ slightly less than that of the initial bed $(\sim 26$ $\mu \mathrm{m})$, but had a near-bed sand fraction (44\%) more than double that of the initial bed (20\%).

Field measurements of suspended sediment on continent shelves during large storms are relatively few. When they have been made, they typically do not include measurements in the lower $10 \mathrm{~cm}$ of the water column, making it difficult to compare our near-bed HDS to field measurements. A notable exception is the recent work on the Eel shelf of northern California. HDS were observed on the Eel mid-shelf during periods of high river discharge and large waves, with orbital velocities of $30-60 \mathrm{~cm} / \mathrm{s}$ and periods of 5-14 s, The wave settings in our experiments were similar to observations of waves on the Eel shelf during storm events (Ogston et al. 2000; Puig et al. 2004; Puig et al. 2003; Traykovski et al. 2000), although 
our wave periods did not span the upper end of those observed on the Eel shelf. The sediment size distribution we used is also similar to observations on the Eel inner to mid shelf (Drake and Cacchione 1985). While the deposits on the mid-shelf from recent floods of the Eel river typically contain a smaller fraction of sand $(<5 \%)$ than we used, these deposits appear to coarsen quickly (presumably from wave reworking) as evidenced by the higher sand content in the underlying strata (Wheatcroft and Borgeld 2000).

The deposits from HDS in our experiments are consistent with observations from cores on the Eel shelf of fine-scale laminae (e.g., Mullenbach and Nittrouer 2000; Wheatcroft and Borgeld 2000) and lenticular bedding interpreted to be the result of stacked rippled and muddy beds (Borgeld et al. 1999). The ripples from our experiments are similar to those observed on the Eel mid-shelf in 50-70 m of water, which typically have wavelengths of approximately $9 \mathrm{~cm}$ (Borgeld et al. 1999; Nakayama 2003) and heights of 0.5 to $1 \mathrm{~cm}$ (Wright et al. 1999). Alternating beds of sand and silt are often thought to be the result of a changing sediment supply, or the advection of sand from a higher-energy environment into the site of interest (Drake 1999). In our experiments, portions of the deposits from HDS as well as the ripples on the bed were significantly coarser than their parent material. Our experiments show that the formation and deposition of HDS can form alternating layers of silt and sand beds in situ without invoking changes in sediment supply.

Applying the revised Richardson number model to the limited field data on HDS on the Eel shelf yields encouraging results. For example, during storm events on the Eel shelf, measurements of HDS indicated near-bed $(<10 \mathrm{cmab})$ sediment concentrations in excess of $10 \mathrm{~g} / \mathrm{l}$ at $60 \mathrm{~m}$ water depth (Traykovski et al. 2000). Unfortunately, measurements less than 10 cmab were obscured by attenuation of the signal from the suspended sediment making it difficult to define the sediment concentration or the lutocline on the basis of a break in the concentration gradient. Nonetheless, using $H=10 \mathrm{~cm}$ and $U_{\max }=61 \mathrm{~cm} / \mathrm{s}$, as was done by Wright et al. (2001), and $\mathrm{Ri}_{\mathrm{c}}=0.03$ yields a depth-averaged concentration of $18.3 \mathrm{~g} / \mathrm{l}$. This estimate seems consistent with the measurements of Traykovski et al. (2000) of $10 \mathrm{~g} / \mathrm{l}$ at $\sim 10 \mathrm{cmab}$. Our near-bed concentrations were usually a factor of two or three greater than our depth-averaged measurements, and thus we suspect that the near-bed sediment concentrations on the Eel shelf were on the order of $36-54 \mathrm{~g} / \mathrm{l}$ at the time of the measurements of Traykovski et al. (2000). It is important to note that these estimates depend linearly on the assumed lutocline height; for example, $H=5 \mathrm{~cm}$ yields depth-averaged concentrations of $36 \mathrm{~g} / \mathrm{l}$, and near-bed concentrations on the order of 72-108 g/l.

If $\mathrm{Ri}_{\mathrm{c}}=0.25$, as argued by Wright et al. (2001), the calculated depthaveraged concentration is $152 \mathrm{~g} / \mathrm{l}$ and $304 \mathrm{~g} / \mathrm{l}$ for $H=10 \mathrm{~cm}$ and $5 \mathrm{~cm}$, respectively. Using $\mathrm{Ri}_{\mathrm{c}}=0.25$ seems unreasonable because it predicts depth-averaged concentrations that are much larger than is often considered the threshold for viscous-dominated flow ( $\sim 80 \mathrm{~g} / \mathrm{l}$ : (Ross and Mehta 1989). A viscous-dominated flow is inconsistent with the observations of Traykovski et al. (2000) of increased near-bed velocity attributed to gravitycurrent behavior. In addition, concentrations of 200-300 g/l are consistent with measured porosities of the (immobile) Eel shelf seafloor (Wheatcroft et al. 1996). Moreover, depth-averaged concentrations of 150-300 g/l seem inconsistent with the measurement of Traykovski et al. (2000) of $\sim 10 \mathrm{~g} / \mathrm{l}$ at $10 \mathrm{cmab}$, unless a very significant (step-like) break in the concentration profile existed below $10 \mathrm{cmab}$.

There are several dissimilarities that might have caused the HDS in our experiments to be different than those observed on the Eel shelf. For example, Traykovski et al. (2000) found that HDS did not form when $\delta_{g m}$ $<5 \mathrm{~cm}$. This is counter to our observations, and might be the result of the lower wave periods in our experiments. For a given orbital velocity, a lower wave period increases the stress on the bed, and therefore makes suspension more likely. Thus the bed stress is probably a more relevant parameter in determining HDS formation than $\delta_{g m}$. In addition, some of the measurements of Traykovski et al. (2001) were made when the shelf was receiving a large load of sediment from the nearby Eel River. Our experiments were not designed to simulate a bottom boundary layer overloaded with sediment from a flooding river. The sediment from the river was almost exclusively mud (Wheatcroft and Borgeld 2000), which might have caused the HDS on the Eel shelf to behave differently than our sandysilt suspensions. For example, Traykovski et al. (2000) observed a lutocline height that scaled with the orbital velocity, where as the lutocline heights in our experiments decreased with orbital velocity because of winnowing. Such winnowing was probably unlikely on the Eel shelf if the bottom boundary layer was being overloaded with fine silt and clay from the Eel River.

Our experiments suggest that HDS might exist on continental shelves in the absence of a flooding river. This is consistent with recent observations of Puig et al. (2003) of HDS on the Eel shelf in $60 \mathrm{~m}$ of water in the absence of direct sediment delivery from the Eel River. After a river flooding event on the Eel shelf, the flood deposits coarsen (presumably due to storm resuspension) and are more similar to the bed composition in our experiments (Wheatcroft and Borgeld 2000). This coarsening is consistent with the observations of ripples at 50-70 m water depths on the Eel midshelf which likely contain large fractions of sand (Borgeld et al. 1999; Nakayama 2003; Wright et al. 1999). Recent work has shown that only $40-50 \%$ of the sand budget can be accounted for on the inner Eel shelf (Crockett and Nittrouer 2004). A significant amount of this sand is likely transported across-shelf, on the basis of observations of significant percentages of sand $(20-60 \%)$ in recently deposited strata $(<100 \mathrm{yrs})$ in the head of Eel canyon (water depth $>100 \mathrm{~m}$ ) (Lomnicky, T.D., Nittrouer, C.A., and Mullenbach, B.L., unpublished work). We hypothesize that HDS formed by wave resuspension in the absence of river flooding might constitute a significant offshore flux of sediment, including sand, if they are advected by an offshore current or flow under the influence of gravity. Further, such HDS might ignite to form turbidity currents (Parker 1982) if they reach sufficient slopes (e.g., Eel submarine canyon) and therefore contribute to offshore sediment transport below wave base.

If measurements in our experiments were limited to concentration and grain size at 10 or $30 \mathrm{cmab}$, as they often are in the field, we might have concluded that the HDS were relatively dilute and composed primarily of mud (Table 1). This suggests the need for future field studies to deploy instrumentation that can measure sediment grain size and concentrations in excess of $10 \mathrm{~g} / \mathrm{l}$ in close proximity to the bed $(<10 \mathrm{cmab})$.

\section{CONCLUSIONS}

We have produced high-density suspensions (HDS) with well-developed lutoclines in an experimental wave facility. These suspensions were turbulent while containing near-bed sediment concentrations ranging from 17 to $80 \mathrm{~g} / \mathrm{l}$ and depth-averaged concentrations of 6-25 g/l, scaling roughly with the orbital velocity. All of the HDS had higher near-bed sand contents (27-78\%) than the initial bed $(\sim 20 \%)$ due to vertical sorting within the HDS and loss of fine sediment to the upper water column. Winnowing of the bed caused more concentrated HDS to be coarser grained, which in turn caused the suspensions to be thinner because of the greater settling velocity of the sediment. Sediment entrainment from the bed into the suspensions was rapid at the beginning of an experiment. Within minutes the HDS reached a quasi-steady state in terms of sediment concentration and lutocline height. Experiments that did not produce definable HDS had lower values of $\mathbf{R}\left(<7.5 \times 10^{4}\right), U_{\text {orb }}(<29 \mathrm{~cm} / \mathrm{s})$, and $C_{\text {bed }}(<11 \mathrm{~g} / \mathrm{l})$.

Our experiments are consistent with the dynamic feedback model of Wright et al. (2001) for quasi-steady suspensions where a bulk Richardson number tends towards a constant value, although it is unclear if the suspensions were limited by sediment-induced stratification or entrainment from the bed. Our computed values of the bulk Richardson number converge to a constant value that is an order of magnitude less than the theorized critical value of Wright et al. (2001); thus their model overpredicts 
the sediment concentration in our experiments by an order of magnitude. Many aspects of our experiments are comparable to observations of fluid mud made on the Eel shelf, California, although more detailed field studies are needed to access whether wave-supported gravity-driven HDS are important in cross-shelf silt and sand transport, in the absence of a flooding river.

\section{ACKNOWLEDGMENTS}

Financial support was kindly provided by the National Science Foundation (EAR0309887), the Office of Naval Research (N000140310138), and the University of Washington. M.P.L. was funded by a National Defense Science and Engineering Graduate Fellowship. Rex Johnson and Randy Fabro built and helped design the Utube, and provided invaluable assistance before and during the experiments. Gavin Fieger performed much of the grain-size analysis. This manuscript improved from early reviews by Joanne Bourgeois, Paul Myrow, and Chuck Nittrouer. We thank Pat Wiberg, Peter Traykovski, and Gail Kineke for comprehensive and insightful reviews that strengthened the final manuscript.

\section{SELECTED NOTATION}

$\begin{array}{ll}A & \text { Wave excursion amplitude } \\ C & \text { Local volumetric concentration } \\ C_{\text {ave }} & \text { Depth-averaged concentration within a high-density suspen- } \\ & \text { sion }\end{array}$

$C_{\text {bed }} \quad$ Concentration from sample taken nearest the bed

$C_{10 \mathrm{cmab}} \quad$ Interpolated concentration at $10 \mathrm{~cm}$ above the bed

$C_{30 \mathrm{cmab}} \quad$ Interpolated concentration at $30 \mathrm{~cm}$ above the bed

$D_{50} \quad$ Grain diameter than which $50 \%$ of the mass distribution is finer

$\overline{D_{50}} \quad$ Depth-averaged $D_{50}$ inside a high-density suspension

$d_{0} \quad$ Orbital diameter

$\delta_{b l} \quad$ Measured boundary layer thickness from Lamb et al. (2004)

$\delta_{g m} \quad$ Calculated boundary-layer thickness from Grant and Madsen (1979)

$f_{w} \quad$ Wave friction factor

$H \quad$ Measured height of HDS

$H_{V M} \quad$ Height of HDS calculated from Vinzon and Mehta (1998)

$H_{10} \quad$ Interpolated elevation where concentration $=10 \mathrm{~g} / \mathrm{l}$

$\eta \quad$ Ripple height

$k_{s} \quad$ Bed roughness length scale

$\lambda \quad$ Ripple wavelength

$R \quad$ Submerged specific density of sediment $(\sim 1.65)$

R Reynolds number

Ri Bulk Richardson number

$T_{w} \quad$ Wave period

$u_{* g m} \quad$ Bed shear velocity calculated from Grant and Madsen (1979)

$U_{\text {orb }} \quad$ Orbital velocity

$w_{s} \quad$ Setting velocity of sediment using Stokes' Law and $D_{50}$

$\%_{\text {sand }}$ bed Percentage of sand from sample taken nearest the bed

$\%$ silt $_{\text {bed }} \quad$ Percentage of silt from sample taken nearest the bed

$\%$ clay $_{\text {bed }} \quad$ Percentage of clay from sample taken nearest the bed

$\%$ sand $_{10 \mathrm{cmab}}$ Interpolated percentage of sand at $10 \mathrm{~cm}$ above the bed

$\%$ sand $_{30 \mathrm{cmab}}$ Interpolated percentage of sand at $30 \mathrm{~cm}$ above the bed

\section{REFERENCES}

ARnotT, W.A., AND Southard, J.B., 1990, Exploratory flow-duct experiments on combinedflow bed configurations for interpreting storm-event stratification: Journal of Sedimentary Research, v. 60, p. 211-219.

Borgeld, J.C., Clarke, J.E.H., Goff, J.A., Mayer, L.A., and Curtis, A., 1999, Acoustic backscatter of the 1995 flood deposit on the Eel shelf: Marine Geology, v. 154, p. 197-210.

Carstens, M.R., Neilson, F.M., and Altinbilek, H.D., 1969, Bedforms generated in the laboratory under oscillatory flow: analytical and experimental study: U.S. Army Corps of Engineers, Coastal Engineering Research Center, Technical Memo 28, p. 39.
Carter, G.S., and GregG, M.C., 2002, Intense, variable mixing near the head of Monterey submarine canyon: Journal of Physical Oceanography, v. 32, p. 3145-3165.

Clifton, H.E., 1976, Wave formed sedimentary structures: a conceptual model, in Davis, R.A Jr., and Ethington, R.L., eds., Beach and Nearshore Sedimentation: SEPM Special Publication 24 , p. 126-148.

Crockett, J.S., and Nittrouer, C.A., 2004, The anatomy of a sandy inner shelf: an example from northern California: Continental Shelf Research, v. 24, p. 55-73.

DingLeR, J.R., 1974, Wave-formed ripples in nearshore sands [unpublished Ph.D. thesis]: University of California, San Diego, 136 p.

DRAKE, D.E., 1999, Temporal and spatial variability of the sediment grain-size distribution on the Eel shelf: the flood layer of 1995: Marine Geology, v. 154, p. 169-182.

Drake, D.E., and Cacchione, D.A., 1985, Seasonal variation in sediment transport on the Russian River shelf, California: Continental Shelf Research, v. 4, p. 495-514.

Dzulynski, S., and Sanders, J.E., 1962, Current marks on firm mud bottoms: Connecticut Academy of Arts and Sciences Transactions, v. 42, p. 57-96.

Grant, W.D., and MadSEN, O.S., 1979, Combined wave and current interaction with a rough bottom: Journal of Geophysical Research, v. 84, p. 1797-1808.

Hamblin, A.P., AND WaLKER, R.G., 1979, Storm-dominated shallow marine deposits: the Fernie-Kootenany (Jurassic) transition, southern Rocky Mountains: Canadian Journal of Earth Sciences, v. 16, p. 1673-1690.

Howard, L.N., 1961, Note on a paper of John W. Miles: Journal of Fluid Mechanics, v. 13, p. $158-160$.

Huppert, H.E., Turner, J.S., and Hallworth, M.A., 1995, Sedimentation and entrainment in dense layers of suspended particles stirred by an oscillating-grid: Journal of Fluid Mechanics, v. 289, p. 263-293.

InMAN, D.L., 1957, Wave generated ripples in nearshore sands: U.S. Army Corps of Engineers, Beach Erosion Board, Technical Memorandum 100, p. 66.

JACKSON, G.A., 1995, Comparing observed changes in particle size spectra with those predicted using coagulation theory: Deep Sea Research Part II: Topical Studies in Oceanography, v. 42, p. $159-184$

Jensen, B.L., Sumer, B.M., And Fredsøe, J., 1989, Turbulent oscillatory boundary-layers at high Reynolds numbers: Journal of Fluid Mechanics, v. 206, p. 265-297.

Justesen, P., 1991, A note on turbulence calculations in the wave boundary layer: Journal of Hydraulic Research, v. 29, p. 699-711.

Kennedy, J.F., And Falcón, M., 1965, Wave generated sediment ripples: Cambridge, Massachusetts, MIT Hydrodynamics Laboratory, Report 86, p. 55.

Kineke, G.C., Sternberg, R.W., Trowbridge, J.H., and Geyer, W.R., 1996, Fluid-mud processes on the Amazon continental shelf: Continental Shelf Research, v. 16, p. 667-696.

Kuenen, P.H., 1968, Settling convection and grain-size analysis: Journal of Sedimentary Petrology, v. 38, p. 817-831.

Lamb, M.P., D'Asaro, E., and Parsons, J.D., 2004, Turbulent structure of high-density suspensions formed under waves: Journal of Geophysical Research, v. 109, No. C12026.

LeEder, M., 1999, Sedimentology and Sedimentary Basins: From Turbulence to Tectonics: Oxford, Blackwell Science, 592 p.

McCool, W., AND Parsons, J.D., 2004, Sedimentation from buoyant fine-grained suspensions: Continental Shelf Research, v. 24, p. 1129-1142.

Middleton, G.V., 1969, Grain flows and other mass movements down slopes, in Stanley, D.J., ed., The New Concepts of Continental Margin Sedimentation: American Geological Institute, Short Course Lecture Notes, p. 1-14.

MiLes, J.W., 1961, On the stability of heterogeneous shear flow: Journal of Fluid Mechanics, v. 10, p. $496-508$.

Mogridge, G.R., and Kamphuis, J.W., 1972, Experiments on bedform generation by wave action: Coastal Engineering, p. 1123-1142.

Mullenbach, B.L., AND NitTrouer, C.A., 2000, Rapid deposition of fluvial sediment in the Eel Canyon, northern California: Continental Shelf Research, v. 20, p. 2191-2212.

Myrow, P.M., And Hiscotт, R.N., 1991, Shallow-water gravity-flow deposits, Chapel Island Formation, southeast Newfoundland, Canada: Sedimentology, v. 38, p. 935-959.

Myrow, P.M., and Southard, J.B., 1996, Tempestite deposition: Journal of Sedimentary Research, v. 66, p. 875-887.

NaKaYama, J.S., 2003, Time-Series Monitoring of Bottom Roughness on the Northern California Continental Shelf [unpublished M.S. thesis]: University of Washington, Seattle, Washington, U.S.A., 29 p.

Ogston, A.S., Cacchione, D.A., Sternberg, R.W., and Kineke, G.C., 2000, Observations of storm and river flood-driven sediment transport on the northern California continental shelf: Continental Shelf Research, v. 20, p. 2141-2162.

Parker, G., 1982, Conditions for the catastrophically erosive turbidity currents: Marine Geology, v. 46, p. 307-327.

Puig, P., Ogston, A.S., Mullenbach, B.L., Nittrouer, C.A., and Sternberg, R.W., 2003, Shelfto-canyon sediment-transport processes on the Eel continental margin (northern California): Marine Geology, v. 193, p. 129-149.

Puig, P., Ogston, A.S., Mullenbach, B.L., Nittrouer, C.A., Parsons, J.D., and Sternberg, R.W., 2004, Storm-induced sediment-gravity flows at the head of the Eel submarine canyon, northern California margin: Journal of Geophysical Research, v. 109, p. 1-10.

Ross, M.A., and MentA, A.J., 1989, On the mechanics of lutoclines and fluid mud: Journal of Coastal Research, Special Issue No. 5, p. 51-61.

SEEd, H.B., 1968, Landslides during earthquakes due to soil liquefaction: American Society of Civil Engineering, Proceedings, Journal of the Soil Mechanics Division, v. 94, p. 10531122.

Smith, J.D., AND McleAn, S.R., 1977, Spatially averaged flow over a wavy surface: Journal of Geophysical Research, v. 82, p. 1735-1746.

Sternberg, R.W., Berhane, I., and Ogston, A.S., 1999, Measurement of size and settling 
velocity of suspended aggregates on the northern California continental shelf: Marine Geology, v. 154 , p. 43-53.

Swift, D.J.P., Gregory, H., and Vincent, C.E., 1986, Fluid processes and sea-floor response on a modern storm-dominated shelf: middle Atlantic Shelf of North America. Part 1: The storm-current regime, in Knight, R.J., and McLean, J.R., eds., Shelf Sands and Sandstones: Canadian Society of Petroleum Geologists, Memoir 11, p. 99-119.

Traykovski, P., Geyer, W.R., Irish, J.D., and Lynch, J.F., 2000, The role of wave-induced density-driven fluid mud flows for cross-shelf transport on the Eel River continental shelf: Continental Shelf Research, v. 20, p. 2113-2140.

Trowbridge, J.H., AND KineKe, G.C., 1994, Structure and dynamics of fluid muds on the Amazon continental shelf: Journal of Geophysical Research, v. 99, p. 865-874.

Turner, J.S., 1973, Buoyancy Effects in Fluids: Cambridge, U.K., Cambridge University Press, $368 \mathrm{p}$.

VAN RiJn, L.C., 1984, Sediment transport, part II: suspended load transport: Journal of Hydraulic Engineering, v. 110, p. 1613-1641.

Verbeek, H., AND CoRnelisse, J.M., 1997, Erosion and liquefaction of natural mud under surface waves, in Burt, N., Parker, R., and Watts, J., eds., Cohesive Sediments: Chichester, U.K. John Wiley \& Sons, p. 353-363.

Vinzon, S.B., AND MehtA, A.J., 1998, Mechanism for formation of lutoclines by waves: Journal of Waterway, Port, Coastal and Ocean Engineering, v. 124, p. 147-149.

WALKER, R.G., 1984, Shelf and shallow marine sandstones, in Walker, R.G., ed., Facies Mod els: Geoscience Canada, Reprint Series 1, p. 141-170.

WALKER, R.G., 1985a, Comparison of shelf environments and deep-basin turbidite systems, in Tillman, R.W., Swift, D.J.P., and Walker, R.G., eds., Shelf Sands and Sandstone Reservoirs: SEPM, Short Course 13, p. 465-502.
WALKER, R.G., 1985b, Geological evidence for storm transportation and deposition on ancient shelves, in Tillman, R.W., Swift, D.J.P., and Walker, R.G., eds., Shelf Sands and Sandstone Reservoirs: SEPM, Short Course 13, p. 243-302.

WhEATCroft, R.A., AND Borgeld, J.C., 2000, Oceanic flood deposits on the northern California shelf: large-scale distribution and small-scale physical properties: Continental Shelf Research, v. 20, p. 2163-2190

Wheatcroft, R.A., Borgeld, J.C., Born, R.S., Drake, D.E., Leithold, E.L., NitTrouer, C.A., and Sommmerfield, C.K., 1996, The anatomy of an oceanic flood deposit: Oceanography, v. 9 , p. $158-162$

WIBERG, P.L., AND HARRIS, C.K., 1994, Ripple geometry in wave dominated environments: Journal of Geophysical Research, v. 99, p. 775-789.

Wikramanayake, P.N., and Madsen, O.S., 1990, Calculation of movable bed friction factors: U.S. Army Corps of Engineers, Coastal Engineering Research Center, Technical Report DACW-39-88-K-0047, p. 105.

WINTERWERP, J.C., 2001, Stratification effects by cohesive and noncohesive sediment: Journal of Geophysical Research, v. 106, p. 22559-22574.

WrIGHT, L.D., KIM, S.C., AND FRIEDRICHS, C.T., 1999, Across-shelf variations in bed roughness, bed stress and sediment suspension on the northern California shelf: Marine Geology, v 154 , p. $99-115$.

Wright, L.D., Friedrichs, C.T., Kim, S.C., AND Scully, M.E., 2001, Effects of ambient currents and waves on gravity-driven sediment transport on continental shelves: Marine Geology, v. 175 , p. $25-45$.

Received 4 February 2004; accepted 13 December 2004. 